\title{
Novel identified receptors on mast cells
}

\author{
Helena Migalovich-Sheikhet ${ }^{1+}$, Sheli Friedman ${ }^{1,2 \dagger}$, David Mankuta ${ }^{2}$ and Francesca Levi-Schaffer ${ }^{1 *}$ \\ 1 Department of Pharmacology and Experimental Therapeutics, Institute for Drug Research, School of Pharmacy, Faculty of Medicine, The Hebrew University of \\ Jerusalem, Jerusalem, Israel \\ ${ }^{2}$ Department of Obstetrics and Gynecology, Hadassah University Hospital, Jerusalem, Israel
}

\section{Edited by:}

Ulrich Blank, INSERM U699,

Université Paris-Diderot Paris 7,

France

Reviewed by:

Ulrich Blank, INSERM U699,

Université Paris-Diderot Paris T,

France

Axel Lorentz, University of

Hohenheim, Germany

\section{*Correspondence:}

Francesca Levi-Schaffer, Department

of Pharmacology and Experimental

Therapeutics, Institute for Drug

Research, School of Pharmacy,

Faculty of Medicine, The Hebrew

University of Jerusalem, POB 12065,

Jerusalem 91120, Israel.

e-mail: francescal@ekmd.huji.ac.il

${ }^{+}$Helena Migalovich-Sheikhet and

Sheli Friedman have contributed

equally to this work.

\begin{abstract}
Mast cells (MC) are major participants in the allergic reaction. In addition they possess immunomodulatory roles in the innate and adaptive immune reactions. Their functions are modulated through a number of activating and inhibitory receptors expressed on their surface. This review deals with some of the most recently described receptors, their expression patterns, ligand(s), signal transduction mechanisms, possible cross-talk with other receptors and, last but not least, regulatory functions that the MC can perform based on their receptor expression in health or in disease. Where the receptor role on $\mathrm{MC}$ is still not clear, evidences from other hematopoietic cells expressing them is provided as a possible insight for their function on MC. Suggested strategies to modulate these receptors' activity for the purpose of therapeutic intervention are also discussed.
\end{abstract}

Keywords: mast cells, activating receptors, inhibitory receptors, ligands, signal transduction, function, costimulation/cross-talk

\section{BACKGROUND}

Mast cells (MC) have the uniqueness of being tissue resident cells packaged with cytoplasmic granules full of preformed mediators of diverse nature, rich in surface receptors that upon ligand binding can induce not only the fast release of the stored mediators, but also the de novo synthesis of arachidonic acid metabolites and a number of chemokines and cytokines. Therefore they play a prominent role in maintaining homeostasis, acting as armed sentinel cells in the tissues, where they reside spanning from mucosal to connective tissues and more. MC have been historically associated with allergy, in which the key receptor is FceRI. However, their strategic location and potential have clearly demonstrated that MC are more than the primum movens of allergic inflammation; they are very important players also in innate and adaptive immune responses, inflammation, and tissue changes. MC immunomodulatory roles may result in either negative or positive outcome for the host, enhancing, or suppressing certain features of immune/inflammatory responses. A large variety of receptors especially activating and some inhibiting MC functions, have been described. FceRI, for IgE activation, and c-kit, the receptor of the stem cell factor (SCF), serve as fingerprints in $\mathrm{MC}$ characterization and are the topic of other reviews of this series.

Our purpose is to review herewith the expression pattern, function, ligand(s), and signal transduction pathways of some of the most recently described activating and inhibiting receptors identified to be expressed by the MC from different origins. We have mainly reviewed the novel activating receptors and discussed just a few examples of the inhibitory ones. The activating receptors are comprised of chemokines, interleukins (IL), amines, Toll-Like Receptors (TLRs), and others (Table 1). For some of the receptors, if known, the physiological and pathological consequences of their activation and the strategies to modulate their activity for the purpose of therapeutic intervention are also discussed. Evidences from other hematopoietic cells expressing these receptors is provided as a possible insight for their function on MC. Potential cross-talk between activating on one side and activating and inhibitory receptors (IRs) on the other side is also briefly considered.

\section{CHEMOKINES RECEPTORS}

Chemokines are small cytokine-like proteins that regulate leukocyte trafficking under homeostatic and inflammatory conditions (Luther et al., 2002; Homey and Bunemann, 2004; for chemokines receptors (CRs), CRs in MC, see review Juremalm and Nilsson, 2005). CRs, expressed on hematopoietic and lymphatic cells, are regulated by a variety of inflammatory stimuli (Olson and Ley, 2002). For example CXCR1 and CXCR2 are expressed on most leukocytes, but appear to be functionally significant only for neutrophils, monocytes/macrophages, and MC. CXCR3, CXCR5, and CXCR6 were found to be expressed on cells of lymphoid lineage (Olson and Ley, 2002). CXCR3 was later found to be expressed also by MC (Juremalm and Nilsson, 2005). A defined set of chemokines (CCL1-5, CCL11, CCL13, CCL17-18, CCL20, CCL22, CCL2627, CX3CL1) was identified to initiate and perpetuate atopic skin inflammation (Homey et al., 2006, 2007). 
Table 1 | Structural functional data, expression, ligand, and function of some MC receptors discussed in the review.

\begin{tabular}{|c|c|c|c|c|}
\hline Receptor & Ligand & Structural functional data & MC expression & Function \\
\hline $\begin{array}{l}\text { Chemokines } \\
\text { receptors }\end{array}$ & $\begin{array}{l}\text { For } \\
\text { CXCR3-CXCL9, } \\
\text { CXCL10, and } \\
\text { CXCL11 (Meiser } \\
\text { et al., 2008) }\end{array}$ & GPCR & $\begin{array}{l}\text { E.g., CXCR3 protein: human lung MC } \\
\text { (Juremalm and Nilsson, 2005) }\end{array}$ & $\begin{array}{l}\text { Migration (Juremalm et al., } \\
\text { 2002), signaling events (Lacotte } \\
\text { et al., 2009) partial degranulation } \\
\text { Willox et al., 2010) }\end{array}$ \\
\hline IL-15R & $\mathrm{IL}-15$ & $\alpha$ Chain, $\beta$ chain, $\gamma$ chain & $\begin{array}{l}\text { Protein: mBMMC Expression assumed by } \\
\text { function: hCBMC (Jackson et al., 2005) }\end{array}$ & $\begin{array}{l}\text { Migration (Jackson et al., 2005), } \\
\text { enhancement of Th1 response, } \\
\text { inhibition of allergic inflammation } \\
\text { in a murine model of asthma } \\
\text { (Ishimitsu et al., 2001) }\end{array}$ \\
\hline IL-18R & $\mathrm{IL}-18$ & $\begin{array}{l}\text { Dimeric complex of IL-18R } \alpha \text {, } \\
\text { IL-18R } \beta\end{array}$ & $\begin{array}{l}\text { mRNA and protein: mouse mucosal MC and } \\
\text { immature MC (Wiener et al., 2008) }\end{array}$ & $\begin{array}{l}\text { Production of IFN } \gamma, \text { GM-CSF, } \\
\text { TNF- } \alpha \text { and IL-1, IL-13, and/or IL-4 } \\
\text { (Nakanishi et al., 2001; Akdis } \\
\text { et al., 2011) }\end{array}$ \\
\hline IL-33R (ST2) & IL-33 & Complex: ST2 and IL-1RAcP & Protein: mBMMC (Liew et al., 2010) & $\begin{array}{l}\text { Degranulation and } \\
\text { proinflammatory cytokine } \\
\text { production and release (Hsu } \\
\text { et al., 2010; Liew et al., 2010) }\end{array}$ \\
\hline TSLPR & TSLP & Complex: TSLPR with IL-7R $\alpha$ & $\begin{array}{l}\text { mRNA: mBMMC (Knisz et al., 2009). Protein: } \\
\text { human peripheral blood and hCBMC } \\
\text { (Allakhverdi et al., 2007) }\end{array}$ & $\begin{array}{l}\text { Increasing of pro-inflammatory } \\
\text { cytokines (Allakhverdi et al., } \\
\text { 2007) production and Th2 } \\
\text { response (Ziegler and Artis, 2010) }\end{array}$ \\
\hline TLR & $\begin{array}{l}\text { Bacterial and viral } \\
\text { proteins }\end{array}$ & $\begin{array}{l}\text { Extracellular leucine rich } \\
\text { region, cytoplasmic domain } \\
\text { that consists of three } \\
\text { homologous regions (box } 1 \text {, } \\
2,3 \text { ) }\end{array}$ & $\begin{array}{l}\text { TLR2 and TLR4 mRNA:immature and mature } \\
\text { MC from murine and human origins } \\
\text { (Supajatura et al., 2002). TLR2 protein: } \\
\text { hCBMC and nasal polyps MC (McCurdy } \\
\text { et al., 2003). TLR2 and TLR4 protein:murine } \\
\text { intestine MC and murine and rat peritoneal } \\
\text { MC (Pietrzak et al., 2011) }\end{array}$ & $\begin{array}{l}\text { de novo synthesis and release of } \\
\text { cytokines (McCurdy et al., 2001; } \\
\text { Supajatura et al., 2002) }\end{array}$ \\
\hline CD48 & $\begin{array}{l}\text { 2B4, FimH, } S \text {. } \\
\text { aureus, and } M \text {. } \\
\text { tuberculosis } \\
\text { toxins }\end{array}$ & $\begin{array}{l}\text { Glycosyl-phosphatidyl-inositol } \\
\text { (GPI)-anchored protein }\end{array}$ & $\begin{array}{l}\text { Protein: BMMC and human peripheral blood } \\
\text { MC }\end{array}$ & $\begin{array}{l}\text { Allergic effector unit formation, } \\
\text { stimulation of mediator release } \\
\text { (Elishmereni et al., 2011) }\end{array}$ \\
\hline S1P2R & S1P & GPCR & $\begin{array}{l}\text { Protein: mBMMC and RBL-2H3 (Jolly et al., } \\
\text { 2004), hMC (Oskeritzian et al., 2010), and } \\
\text { hematopoietic progenitors (Price et al., 2009) }\end{array}$ & $\begin{array}{l}\text { Degranulation Wang et al., 2012) } \\
\text { and chemokine and cytokine } \\
\text { release (Oskeritzian et al., 2010) } \\
\text { trafficking and migration (Spiegel } \\
\text { and Milstien, 2011) }\end{array}$ \\
\hline \multirow[t]{3}{*}{$\begin{array}{l}\mathrm{HR}\left(\mathrm{H}_{1}, \mathrm{H}_{2}, \mathrm{H}_{3},\right. \\
\left.\mathrm{H}_{4}\right)\end{array}$} & Histamine & GPCR & $\begin{array}{l}\text { H1R mRNA and protein: (Lippert et al., 2004) } \\
\text { low in human skin MC (Lippert et al., 2004; } \\
\text { Gibbs and Levi-Schaffer, 2012), higher in } \\
\text { HMC-1 cells }\end{array}$ & $\begin{array}{l}\text { H1, H2-intracellular calcium } \\
\text { mobilization (Tilly et al., 1990) }\end{array}$ \\
\hline & & & $\begin{array}{l}\text { H2R mRNA and protein: human skin MC, } \\
\text { and HMC-1 cells (Lippert et al., 2004) }\end{array}$ & $\begin{array}{l}\text { H3-autoregulation of histamine } \\
\text { release (Ohkubo et al., 1994) }\end{array}$ \\
\hline & & & $\begin{array}{l}\mathrm{H}_{3} \mathrm{R} \text { protein: in brain mast cells (Rozniecki } \\
\text { et al., 1999) } \\
\text { H4R mRNA: mouse MC, hCBMC, and } \\
\text { HMC-1 (Hofstra et al., 2003; Gibbs and } \\
\text { Levi-Schaffer, 2012), human skin MC (Lippert } \\
\text { et al., 2004) }\end{array}$ & $\begin{array}{l}\text { H4-chemotaxis and intracellular } \\
\text { calcium mobilization in mMC } \\
\text { (Nordlind et al., 2008), } \\
\text { recruitment of effector cells in } \\
\text { human (Hofstra et al., 2003) }\end{array}$ \\
\hline
\end{tabular}


Table 1 | Continued

\begin{tabular}{|c|c|c|c|c|}
\hline Receptor & Ligand & Structural functional data & MC expression & Function \\
\hline $5 \mathrm{HTR}$ & Serotonin & GPCR & $\begin{array}{l}\text { mRNA: mBMMC and human CD34+-derived } \\
\text { MC (Kushnir-Sukhov et al., 2006) }\end{array}$ & $\begin{array}{l}\text { Cell migration (Nordlind et al., } \\
\text { 2008) }\end{array}$ \\
\hline $\mathrm{P} 2 \mathrm{X}$ & ATP & P2X: ion pore & $\begin{array}{l}\text { E.g., } \mathrm{P} 2 \mathrm{X}_{1}, \mathrm{P} 2 \mathrm{X}_{4}, \mathrm{P} 2 \mathrm{X}_{7} \text { protein: } \\
\text { hCBMC(Bulanova and Bulfone-Paus, 2010). } \\
\text { P2 } \mathrm{X}_{1-4}, \mathrm{P} 2 \mathrm{X}_{6-7} \text { mRNA: mBMMC (derived } \\
\text { from C57BL/6 mice) }\end{array}$ & $\begin{array}{l}\text { Degranulation, apoptosis } \\
\text { (Bulanova et al., 2009) }\end{array}$ \\
\hline CD203c & $\begin{array}{l}\text { NAD and } \\
\text { nucleotide sugars }\end{array}$ & $\begin{array}{l}\text { Type II-phosphatidyl-inositol } \\
\text { transmembrane proteins with } \\
\text { catalytic domain and a } \\
\text { C-terminal endonuclease-like } \\
\text { domain }\end{array}$ & $\begin{array}{l}\text { mRNA and protein: overexpressed on } \\
\text { neoplastic MC in patients with systemic } \\
\text { mastocytosis (Hauswirth et al., 2008) }\end{array}$ & $\begin{array}{l}\text { Cleavage of phosphodiester and } \\
\text { phosphosulfate bonds (Buhring } \\
\text { et al., 2004) }\end{array}$ \\
\hline $\mathrm{CRHR}$ & $\mathrm{CRH}$ & GPCR & $\begin{array}{l}\text { mRNA and protein: hCBMC and LAD-2 } \\
\text { (Asadi et al., 2012) }\end{array}$ & $\begin{array}{l}\text { Production and release of IL-8, } \\
\text { TNF, VEGF. Induction of NK-1 } \\
\text { gene expression (Asadi et al., } \\
\text { 2012) }\end{array}$ \\
\hline
\end{tabular}

mRNA, messenger ribonuclear acid; MC, mast cell; IL, interleukin; GPCR, G protein coupled receptor; $H$, human; $M$, mouse; BMMC, bone marrow mast cells; CBMC, cord blood mast cells; IFN $\gamma$, interferon-gamma; GM-CSF, granulocyte-macrophage colony-stimulating factor; TNF $\alpha$, tumor necrosis factor $\alpha$; TSLPR, thymic stromal lymphopoietin receptor; TLR, Toll-like receptor; 5HTR, 5-hydroxytryptamine receptors; ATP, ADP, adenosine 5-triphosphate, adenosine diphosphate; UTP, UDP, uridine triphosphate, uridine diphosphate; $N A D$, nicotinamide adenine dinucleotide; $C R H R$, corticotropin-releasing hormone receptor; $C R H$, corticotropin-releasing hormone; SCF, stem cell factor; S1P, sphingosine-1-phosphate; HR, histamine receptor.

Human MC (hMC) from different origins express at least nine CRs, i.e., CXCR1-4, CX3CR1, CCR1 (further detailed in MC Co-Stimulation), CCR3-5 that may be activated by the respective chemokines, i.e., CXCL1, CXCL5, CXCL8, CXCL14, CX3CL1, CCL5, and CCL11 (Juremalm and Nilsson, 2005). Interestingly, activation of CRs on MC can not only induce their chemotaxis, but also other stimulatory responses. For example, the activation of CXCR3 and CCR2, besides migration also induces human cord blood MC (hCBMC) signaling events or even partial degranulation in the absence of antigen (Willox et al., 2010). The expression of CXCR3 and RANTES (also known as CCL5) on MC is important especially in the migration of MC precursors in the tissues where they undergo final maturation (Juremalm et al., 2002). CCL5/RANTES can induce MC migration through interactions with CCR1 and CCR4 (Juremalm et al., 2002).

CXCR3 is a seven transmembrane (TM) domain G protein coupled receptor (GPCR) that binds the pro-inflammatory, non-ELR motif of CXC chemokines: CXCL9, CXCL10, and CXCL11 (Meiser et al., 2008) and was found to be sensitive to pertussis toxin (Ptx; Willox et al., 2010). Recently, two different variants of CXCR3 have been identified in human: CXCR3B and CXCR3-ALT, both originating from the same gene and produced by alternative splicing of the CXCR3 mRNA (Willox et al., 2010). CXCR3 activation leads to $\mathrm{G} \alpha \mathrm{i}$ protein internalization with subsequent calcium influx 
and triggering of mitogen-activated protein kinases (MAPK) and AKT (Protein kinase B, PKB) cascade resulting in cytoskeleton rearrangement and cell movement (Lacotte et al., 2009). Upon activation of this CR, cross-talk between the CXCR3 and FCERI is possible due to the fact that both these receptors involve phosphoinositide 3-kinases (PI3Ks) signaling. CXCR3 is highly expressed in human lung MC that reside in proximity to the smooth muscle in asthmatics, but is not expressed in human bone marrow MC (hBMMC; Brightling et al., 2005). In human lungs, CXCR3 on $\mathrm{MC}$ mediates their migration toward chemokines-secreting airway smooth muscle regions. Additionally, CXCL10 has been shown to be expressed in that region in bronchial asthma biopsy specimens and ex vivo in smooth muscle cells from asthmatics compared to the ones derived from healthy volunteers (Okayama et al., 2008). Because of the importance of chemokines in recruiting inflammatory cells and MC precursors into the tissues, neutralization of chemokines, or antagonists of their receptors is an active investigational field in the pharmaceutical industry.

\section{INTERLEUKIN RECEPTORS AND TSLPR}

Interleukins are secreted glycoproteins that bind to their specific receptors and play a role in the communication among leukocytes. In the past decade, a number of new cytokines have been described such as IL-15, IL-18, IL-7, IL-33. Importantly, MC display the receptors for some of the newly identified IL.

\section{THE IL-15 RECEPTOR}

The classic IL-15 receptor $(I L-15 R)$ consists of a unique $\alpha$ chain, a $\beta$ chain, and a common $\gamma$ chain which is shared with the IL-2 receptor (Lorenzen et al., 2006). IL-15R signaling requires DAP10associated proteins since the IL-15 signaling pathway phosphorylates DAP10 through JAK3. Once activated, IL-15R triggers the activation of JAK3-STAT5 signaling pathway that relays information to the nucleus (Colucci, 2007). IL-15R is expressed in B, T cells, and natural killers cells (NK) and its activation results in cell proliferation and differentiation. IL-15R was recently reported to be expressed on mouse BMMC (mBMMC). It has not yet been reported whether hCBMC express the same receptors. However, IL-15 induced migration of both mBMMC and hCBMC in a dose-responsive and biphasic manner, supports the possibility that this effect is mediated by two distinct IL-15R with different affinities to IL-15 (Jackson et al., 2005). Interestingly, in stimulated dendritic cells (DC), IL-15, and IL-15R $\alpha$ are preassembled in complexes within the endoplasmic reticulum/Golgi before being released from the cells. In NK, membrane bound IL-15-IL-15R $\alpha$ complexes, and not the soluble ones, trigger activation (Mortier et al., 2008).

The ligand of IL-15R, IL-15, is produced in human by both non-immune cells (keratinocytes and skeletal muscle cells) and by immune cells (monocytes, and activated CD4+ T cells) in response to signals that induce innate immunity (Akdis et al., 2011). IL-15 is also produced by murine MC, especially after stimulation with lipopolysaccharide (LPS; Orinska et al., 2007). IL-15 in $\mathrm{MC}$ induces an intracrine signal that downregulates chymasedependent, MC-mediated innate immunity (Orinska et al., 2007). In $I l-15^{-1-}$ mice, the absence of IL-15 in MC increases chymase activities, leading to greater MC bactericidal responses, increased processing, and activation of neutrophil-recruiting chemokines, and improved sepsis survival (Orinska et al., 2007).

IL-15 is associated with autoimmune and inflammatory diseases and was recently shown to be upregulated in T cell-mediated inflammatory disorders, such as rheumatoid arthritis (RA) and inflammatory bowel diseases (Waldmann, 2004). In rheumatoid synovial tissue explants, $\alpha \operatorname{IgE}$ induced MC activation induces changes in the amounts of released tryptase, TNF $\alpha$, and IL- $1 \beta$ by a proportion of mononuclear inflammatory cells, but not in the amount of IL-15 (Woolley and Tetlow, 2000). IL-15 is also associated with the development of X-linked severe combined immunodeficiency (Akdis et al., 2011). Overexpression of IL-15 in vivo enhances Th1 responses, which inhibit allergic inflammation in a murine model of asthma (Ishimitsu et al., 2001). In a human psoriasis xenograft model, the anti IL-15 antibody $146 \mathrm{~B} 7$ was found to be involved in the reduction of the severity of the disease (Villadsen et al., 2003). Additionally, HuMax-IL-15, a human IgG1 anti-IL-15 monoclonal antibody, that in vitro was able to neutralize exogenous and endogenous IL-15, has been used for clinical trials in patients with RA to perform a phase I-II dose-escalation trial (Baslund et al., 2005; Waldmann, 2006).

\section{THE IL-18 RECEPTOR}

IL-18 receptor (IL-18R) expressed on MC belongs to the IL1 receptor (IL-1R) family (Thomassen et al., 1998). IL-18R $\alpha$ is the binding chain and together with IL-18R $\beta$ form a high affinity heterotrimeric complex with the ligand IL-18. This complex recruits the intracellular adapter molecules myeloid differentiation primary response protein 88 (MyD88), IL-1 receptor-associated kinases (IRAK) and tumor necrosis factor receptor associated factor 6 (TRAF6) which results in the activation of p38 MAPK, JUN $\mathrm{N}$-terminal kinase (JNK), and/or nuclear factor kB (NF-kB; Arend et al., 2008). IL-18R is expressed on T cells, NK cells, macrophages, epithelial cells, chondrocytes (Kunikata et al., 1998), and MC (Helmby and Grencis, 2002).

The ligand of IL-18R, IL-18, is an IFN- $\gamma$-inducing factor and a potent cytokine that is produced by monocytes/macrophages as a reaction to different microbial components and therefore plays a major role in the innate immune responses to pathogens (Arend et al., 2008). Also Kupffer cells, keratinocytes, osteoblasts, astrocytes, and DC express IL-18 (Akdis et al., 2011). The regulation of IL-18 biological activity is carried out by caspase-1-mediated cleavage of pro-IL-18 to the mature protein. Human chymase can also cleave pro-IL-18 to the active protein (Omoto et al., 2006). IL18 binding protein $(\mathrm{BP})$ is a soluble protein that by binding mature IL-18 prevents its binding to receptor, and therefore serves as a natural inhibitor (Novick et al., 1999). IL-18BP displays four isoforms in humans and two in mice that are the result of alternative splicing of mRNA and which mainly differ in the C-terminal region. IL-18 indirectly increases the production of its own inhibitor in a feedback loop via INF $\gamma$ secretion. IL-18R activation is able to induce in addition to IFN $\gamma$, also GM-CSF, TNF $\alpha$, and IL-1 production. In addition it can induce IL-13 and/or IL-4 production by NK, MC, and basophils. It can therefore enhance innate immunity and both Th1 and Th2 driven immune responses (Nakanishi et al., 2001).

IL-18 has been associated with autoimmune diseases or inflammatory disorders, bronchial asthma (Harada et al., 2009), atopic 
dermatitis (Konishi et al., 2002), RA (Gracie et al., 1999; PlaterZyberk et al., 2001), psoriasis (Ohta et al., 2001), multiple sclerosis (Karni et al., 2002), and type I diabetes (Altinova et al., 2008; Akdis et al., 2011). Regarding allergy, interestingly IL-18 contributes to the spontaneous development of IgE/signal transducer and activator of transcription (STAT6)-independent atopic dermatitis-like inflammatory skin lesion (Konishi et al., 2002).

In conclusion, IL-18/IL-18R regulation, if carried out by selective antagonists, can possibly be considered as a good pharmacological target in either Th1 or Th2 driven conditions.

\section{IL-33 RECEPTOR}

IL-33 receptor $(I L-33 R)$ termed also ST2 is a member of the IL1R family, and TLR/IL-1R (TIR) superfamily (Liew et al., 2010). It binds IL-33 as a heterodimer consisting of ST 2 and IL-1R accessory protein. The signaling cascade of ST2 activation involves recruitment of MyD88, TRAF6, and IRAK. This leads to NF-kB activation and the activation of MAPK p38, signal-regulated kinase ERK, and JNK. ST2 is expressed on basophils, MC, eosinophils, NK cells, Th2 cells, DC, and nuocytes (Kunikata et al., 1998; Akdis et al., 2011).

Mouse BMMC express high levels of ST2 and respond directly to IL-33 to produce a spectrum of inflammatory cytokines and chemokines (IL-1, IL-6, IL-13, TNF, CCL2, and CCL3; Liew et al., 2010). In vivo, IL-33 treatment exacerbated collagen-induced arthritis in $S T 2^{-1-} \mathrm{KO}$ mice engrafted with MC from WT but not from $S T 2^{-1-}$ mice, a fact that was associated with elevation in expression levels of pro-inflammatory cytokines (Xu et al., 2008). The ST2 ligand, IL-33, is a pro-inflammatory cytokine that activates Th2 response-inducing cells. IL-33 activation induces mBMMC and the murine MC line MC/9 proliferation and Th2 cytokine production including IL-4, IL-5, IL-6, but not IL-33 itself (Hsu et al., 2010). On the other hand mBMMC produce IL-33 in response to $\mathrm{IgE}$ activation, which requires calcium influx or ionomycin activation (Hsu et al., 2010).

IL-33/ST2 pathway is critical for the development of IgE-driven tissue inflammation during passive cutaneous anaphylaxis that is a strictly MC-dependent model (Hsu et al., 2010). Levels of soluble ST2 increase in inflammatory conditions such as systemic lupus erythematosus (SLE), RA (Xu et al., 2008), idiopathic pulmonary fibrosis (Tajima et al., 2003), asthma (Oshikawa et al., 2001), progressive systemic sclerosis, Behcet's disease, Wegener's granulomatosis, severe trauma, and sepsis (Akdis et al., 2011). Importantly, in all of these conditions MC activation and role have been illustrated. IL-33 release is elevated in skin of patients with atopic dermatitis (Liew et al., 2010). Constant mechanical microtrauma and destruction of skin barrier induce IL-33 release and a pro-inflammatory response. In addition, IL-33 may play a role in psoriasis-like plaque inflammation (Hueber et al., 2011).

IL-33 has been classified as an alarmin/danger signal (Cevikbas and Steinhoff, 2012) since it is released by cells undergoing necrosis and it is inactivated by caspases during cell apoptosis (Liew et al., 2010; Hueber et al., 2011). However, it is evident that IL-33 is released not only from necrotic cells, but also from living cells and therefore acts as a classical cytokine (Liew et al., 2010). Its importance in allergy is the current topic of high interest partly due to its effects on the MC.

\section{TSLP RECEPTOR}

TSLP receptor (TSLPR) is the receptor of TSLP that is an IL-7-like cytokine initially identified in the culture supernatant of a thymic stromal cell line (He and Geha, 2010). TSLPR has a low affinity to TSLP, but together with IL-7R $\alpha$ they generate high affinity binding sites and trigger signaling (Park et al., 2000). Cross species homology of TSLP and its receptor is relatively low (about 40\%; He and Geha, 2010; Ziegler and Artis, 2010), but the fact that both in human and in mouse IL-7R $\alpha$ is required suggests that human TSLP and TSLPR are orthologs to mouse TSLP and TSLPR. The signaling cascade of these receptors is not completely clear and no Janus kinases (JAK) are activated (Isaksen et al., 2002). It has however been shown that receptor engagement can activate the transcription factor STAT3 in human and STAT5 in mouse and human (Isaksen et al., 2002). In addition, it can also induce the expression of common genes (such as Cish; Isaksen et al., 2002).

TSLP receptor is expressed on hematopoietic cell lineages, including B cells, T cells, MC, eosinophils, and DC (Taylor et al., 2009). mBMMC were shown to express TSLPR mRNA (Knisz et al., 2009). TSLPR and IL-7R $\alpha$ chain expression were determined at the mRNA level on human peripheral blood and hCBMC (Allakhverdi et al., 2007). In spite of these reports, human peripheral blood derived MC (hpbMC) and the HMC-1 cell line (hMC leukemia-1) were found by us to express TSLPR, but not IL-7R (Levi-Schaffer, F., Soumelis, V., Levy, I., unpublished data). At the protein level, TSLPR was also reported to be expressed in vivo on MC infiltrating the bronchial mucosa of asthmatic patients, as revealed by immunostaining of biopsy specimen (Allakhverdi et al., 2007; Comeau and Ziegler, 2010; Shikotra et al., 2012).

It has been found that MC infiltrating to the mucosal gland stroma and airway smooth muscle in asthma not only express high levels of TSLP mRNA, but can also respond to TSLP (Rochman and Leonard, 2008). TSLP can directly activate hMC to produce pro-inflammatory Th2 cytokines and chemokines in the presence of IL- $1 \beta$ and tumor necrosis factor $\alpha$ (TNF- $\alpha$ ), in a way that mimics inflammation conditions (Allakhverdi et al., 2007). Various cell types can produce TSLP: endothelial, epithelial cells and epidermal keratinocytes, airway smooth muscle cells, fibroblasts, DC, trophoblasts, and cancer or cancer-associated cells (Takai, 2012). hMC express TSLP mRNA, which is upregulated upon crosslinking of the IgE receptor. Pre-incubation with IL-4 results in significant upregulation of IgE-mediated TSLP protein and mRNA expression (Okayama et al., 2009; Comeau and Ziegler, 2010).

TSLP plays a significant role in initiation of allergic inflammation and is very important to cells such as the MC, due to its high expression in the interfaces between the body and environment and its ability to lead to Th2 responses (Ziegler and Artis, 2010). Different studies have shown that asthma, allergic rhinitis, and atopic dermatitis are characterized by an increased expression of TSLP in the inflamed tissue (Ziegler and Artis, 2010; Le et al., 2011). Mice overexpressing TSLP on TCR $\beta^{-1-}$ background, develop dermal inflammation and skin infiltrates of MC and eosinophils (Yoo et al., 2005). MC deficient mice failed to upregulate TSLP in nasal epithelium after allergen challenge in a model of allergic rhinitis (Ziegler and Artis, 2010). In asthma it was demonstrated that MC play an important role in TSLP production (Shikotra et al., 2012). TSLP levels are increased in human asthma and correlate with the 
increase in expression of Th2 cytokines and disease severity (Ying et al., 2005, 2008; Corrigan et al., 2009; Fang et al., 2010).

Blocking of TSLP signaling using TSLPR-immunoglobulin in murine asthma model, was shown to regulate pulmonary DC function and to reduce eosinophilic airway inflammation and Th2 differentiation significantly (Zhang et al., 2011). Additionally, TSLP/TSLPR interaction influences the function of cells in host protection against helminth parasites, and modulates gut homeostasis in conditions in which MC are involved (Comeau and Ziegler, 2010). Therefore it appears that MC displaying TSLPR and producing TSLP have a potent weapon in addition to FcERI in orchestrating the allergic reactions. As a consequence the TSLP axis is a very promising candidate for anti-allergic intervention.

Notably, TSLP and IgE stimulated MC can induce OX40 ligand (OX40L) expression on DC. (Ito et al., 2005; Edwards, 2008). OX40 receptor and its ligand OX40L belong to the superfamilies TNF receptor and TNF respectively (Godfrey et al., 1994) and were shown to have a crucial role in allergic inflammation. OX40/OX40L interaction can trigger the differentiation of some inflammatory Th2 cells in the lymph nodes. (Liu, 2007; Wang and Liu, 2007) OX40L on MC and OX40 on T regulatory cells crosstalk can induce $\mathrm{T}$ cells activation by hMC in vitro (Kashiwakura et al., 2004) and inhibit FceRI-dependent MC degranulation both in vitro and in vivo (Gri et al., 2008). Recently, Ilves and Harvima (2012) showed that there are more OX40 positive cells in the dermis from $\mathrm{AD}$ lesions than in healthy looking dermis, which does not correlate with clinical severity of AD.

\section{TOLL-LIKE RECEPTORS AND OTHER BACTERIAL AND VIRAL RECEPTORS}

As key protagonists of innate immunity, MC play a pivotal role in anti-infection defense and "danger" responses. MC reactivity against bacteria have been more characterized than the ones against viruses, although both of them are classically mediated by TLRs (Akira and Takeda, 2004), a family of pattern recognition molecules.

Toll-like receptors and IL-1R have a conserved cytoplasmic domain that consists of three homologous regions (boxes 1,2,3) and an extracellular domain that differs: TLRs have tandem repeats of leucine rich regions, while IL-1R has three immunoglobulin like domains (Akira and Takeda, 2004). Stimulation of TLR triggers the association of MyD88, IRAK4, and IRAK1 signaling leading to the NF-kB activation and gene expression (Akira and Takeda, 2004). MC signaling via TLRs involves also ITAM-containing molecule DAP12 phosphorylation that activates syk, which is a critical molecule of MC activation (Smrz et al., 2010). This would suggest a cross-talk between TLRs and receptors that employ DAP12 as a transducer molecule.

TLR2 and TLR4 expression has been detected at the mRNA level in immature and mature MC from murine and human origins (Supajatura et al., 2002). At the protein level, TLR2 was found to be expressed in hCBMC and in nasal polyps MC (McCurdy et al., 2003). TLR2 and TLR4 are found in murine intestine MC and murine and rat peritoneal MC (Pietrzak et al., 2011). TLR signaling events induce cytokine production (Supajatura et al., 2002). TLR2 can be activated by prolonged stimulation with bacterial wall components, such as LPS and peptidoglycan (PGN), resulting in de novo synthesis and release of various cytokines. It was shown that PGN was able to induce degranulation of $\mathrm{mBMMC}$ via TLR2 accompanied by $\mathrm{Ca}^{2+}$ influx, whereas the activation of MC by LPS via TLR4 did not lead to degranulation (Supajatura et al., 2002). Cytokine exposure of MC can also upregulate the expression of TLRs. For example, IL- 6 treatment of mMC induces an increase in TLR4 expression, whereas exposure to TNF does not influence the TLR2 and TLR4 protein levels (McCurdy et al., 2001). On the contrary, exposure of MC to CCL5 resulted in decreased expression of both TLR2, following $24 \mathrm{~h}$ incubation, and TLR4 level, following 12 and $24 \mathrm{~h}$ incubation (McCurdy et al., 2001).

\section{CD48}

CD48, a CD2-like molecule, is a $40 \mathrm{KD}$ glycosyl-phosphatidylinositol (GPI)-anchored protein, expressed on the surface of hematopoietic cells (recently reviewed in Elishmereni and LeviSchaffer, 2011). The CD48 structure combines a distal V-like domain with a $\mathrm{C} 2$-like domain containing conserved cysteine residues that form disulfide bonds. It lacks a TM domain and is attached to the cell surface by a glycolipid, GPI, restricted to the outer leaflet of the membrane bilayer (Shin and Abraham, 2001). $\mathrm{CD} 48$ is found also in soluble form, due to its cleavage upon activation. Stimulated CD48 associates to the kinase LCK and leads to tyrosine phosphorylation (Elishmereni and Levi-Schaffer, 2011).

CD48 is illustrated here since in MC, CD48 was first described to be involved in innate immunity as it binds FimH of E. coli. This interaction triggers a strong TNF- $\alpha$ release and the uptake of this Gram-bacteria (Malaviya et al., 1999; Malaviya and Abraham, 2001; Proft and Baker, 2009). CD48, has also been implicated in MC interactions with $M$. tuberculosis, which triggers the release of several pre-stored mediators, such as histamine and $\beta$ hexosaminidase, and the de novo synthesis of cytokines, such as TNF- $\alpha$ and IL-6 (Munoz et al., 2003). Later on we found that S. aureus, a Gram+ bacteria, and its toxins bind to CD48 and TLR2 on hCBMC causing subsequent release of pro-inflammatory cytokines (Rocha-de-Souza et al., 2008). CD48 is overexpressed in murine asthma and was defined as a signature gene in this condition (Zimmermann et al., 2003). The CD48 ligand in human is 2B4, expressed by several hematopoietic cells. CD48/2B4 interactions taking place between $\mathrm{MC}$ and eosinophils are important in allergic inflammation giving rise to the physical formation of the allergic effector unit (AEU) between these two cells (Elishmereni et al., 2011). CD48-2B4 binding induces degranulation of MC and increases eosinophil survival and activation (Elishmereni et al, 2011). In a murine model of allergic asthma, treatment with neutralizing CD48 Ab dramatically inhibited the lung inflammation (Munitz et al., 2007). Therefore it seems that CD48 is a good candidate to be blocked on MC in order to avoid both AEU formation and bacterial invasion, with this last property being particularly helpful in allergic conditions, such as atopic dermatitis, that are commonly associated with $S$. aureus infection.

\section{S1P RECEPTORS}

$S 1 P R_{1-5}$ are GPCRs of sphingosine-1-phosphate (S1P). Secretion of S1P by MC can modulate their function by binding to $S 1 \mathrm{PR}_{1}$ and $\mathrm{S}_{1} \mathrm{PR}_{2}$ found on MC, in an autocrine fashion (Spiegel and Milstien, 2011). It was shown on DC that there is a cross-talk 
between $S 1 P_{2}$ and $S 1 P R_{1}$, when upregulation of $S 1 P_{2}$ activates the small GTPase RHO leading to translocation of Four and a Half LIM domains protein 2 (FHL2) to the nucleus and downregulates $\mathrm{S}_{1} \mathrm{PR}_{1}$ expression. On the other hand, downregulation of S1PR 2 increases $\mathrm{S}_{\mathrm{PR}}$ expression and RAC activation (Spiegel and Milstien, 2011).

$\mathrm{S}_{1} \mathrm{P}_{1}$ is involved in the migration of $\mathrm{MC}$ toward low concentrations of antigen, while $\mathrm{S}_{2} \mathrm{P}_{2}$ participates in FceRI-induced degranulation (Jolly et al., 2005; Olivera, 2008). S1P released from $\mathrm{MC}$ after cross-linking of $\mathrm{Fc \varepsilon RI}$, and their $\mathrm{S}_{1} \mathrm{P}_{2}$ receptors are critical for degranulation and chemokine, cytokine, and lipid mediator release from activated human and rodent $\mathrm{MC}$ (Oskeritzian et al., 2010). Additionally, blocking of the S1P-S1PR 2 axis was shown to drastically reduce circulating levels of histamine in a mouse anaphylaxis model indicating that MC were inhibited (Oskeritzian et al., 2010). The $S 1 \mathrm{PR}_{2}$ activation plays a role in anti-viral immunity: the viral membrane lipid sphingomyelin that is converted in the cell membrane to $\mathrm{S} 1 \mathrm{P}$ can then activate the $\mathrm{S} 1 \mathrm{PR}_{2}$ in an autocrine manner to stimulate $\mathrm{MC}$ degranulation (Wang et al., 2012). S1P-S1PR 1 axis has been shown to be expressed on and to control the trafficking and migration of numerous types of immune cells, including $\mathrm{T}$ and $\mathrm{B}$ lymphocytes, natural killer $\mathrm{T}$ cells, DC, macrophages, neutrophils, hematopoietic progenitors, MC, and osteoclasts (Spiegel and Milstien, 2011).

Therefore, S1PR can offer an interesting pharmacological target for a number of immune diseases. For example the $\mathrm{S}_{\mathrm{PR}} \mathrm{PR}_{2}$ antagonist JTE013 significantly inhibited $\mathrm{H}_{2} \mathrm{O}_{2}$-induced permeability in the rat lung perfused model (Sanchez et al., 2007). More studies are under way to exploit the blockage of the S1P and its receptors in many diseases and notably in allergy.

\section{AMINES' RECEPTORS}

Among the mediators extensively identified with the function of MC in allergy, histamine in humans and rodents, and serotonin especially in rodents are key factors influencing the activity of a number of target cells/organs. MC not only produce these two potent amines but also display some of their receptors (Gibbs and Levi-Schaffer, 2012; Ritter et al., 2012).

\section{HISTAMINE RECEPTORS}

Histamine receptors (HRs) are GPCRs with seven TM-spanning helices. Until now, four subtypes of human HRs have been identified: H1R, H2R, H3R, and H4R. H1R and H2R have been the focus of many studies (recently reviewed in Gibbs and Levi-Schaffer, 2012). Fewer studies have been performed on the H3R and even less on the newest identified one, H4R. Regarding HRs expression by MC, not much work had been carried out until the recent discovery of H4R.

$\mathrm{H} 1 \mathrm{R}$ expression has been described on human skin $\mathrm{MC}$ to be low (Lippert et al., 2004; Gibbs and Levi-Schaffer, 2012), while on the HMC-1 cells it is higher (Lippert et al., 2004). H1R antagonists can inhibit MC activation and therefore can be used as antiallergic/MC stabilizing drugs (Levi-Schaffer and Eliashar, 2009), even though some of them might increase cellular cAMP in competitive antagonism with $\mathrm{H} 2 \mathrm{R}$. In cholangiocytes, H1R acts by $\mathrm{G} \alpha \mathrm{q}$ activating $\mathrm{IP}(3) / \mathrm{Ca}^{2+}$, whereas $\mathrm{H} 2 \mathrm{R}$ activates $\mathrm{G} \alpha(\mathrm{s})$ stimulating cAMP (Francis et al., 2012). Additionally, it was reported that $\mathrm{H} 2 \mathrm{R}$ can activate both adenylate cyclase and phospholipase
C signaling pathways via separate GTP-dependent mechanisms (Wang et al., 1996). Interestingly, via the H2R, histamine displays a net inhibitory action on MC (Gibbs and Levi-Schaffer, 2012). H2R is expressed on human skin MC, on HMC-1 cells and basophils, and perhaps on human lung MC. The $\mathrm{H} 2$ agonist impromidine was shown to inhibit MC activated with compound 48/80 and this inhibition was reversed by the histamine antagonists (Masini et al., 1982).

H3R and H4R have about 40\% sequence homology and are functionally related (Morse et al., 2001; Zhu et al., 2001). Both of them are activated by $\alpha$-methylhistamine (H3/4R agonist) and inhibited by thioperamide (antagonist). Mouse MC were reported to express H4R and to lack H3R expression (except brain MC that do express H3R; Pillot et al., 2002; Gibbs and Levi-Schaffer, 2012). In mouse $\mathrm{MC}$, the $\mathrm{H} 4 \mathrm{R}$ has been shown to couple to $\mathrm{Ca}^{2+}$ mobilization, but not to cAMP, in a Ptx-sensitive manner (Hofstra et al., 2003; Rosethorne and Charlton, 2011). H4R in mouse MC affects chemotaxis and intracellular calcium mobilization, and although it is not involved in their degranulation, the receptor activation and subsequent histamine release leads to recruitment of effector cells, especially eosinophils, rich in H4R to the site of chronic allergic inflammation (Hofstra et al., 2003). H4R activation of murine MC increases leukotriene B4 (LTB4) release and supports neutrophil recruitment induced by zymosan (Takeshita et al., 2003). H4R blockade was shown to decrease MC and eosinophil migration to the airway epithelial tissue after guinea pigs allergen exposure (Yu et al., 2008). Blocking the H4R also decreases the MC migration in presence of CXCL12 in vitro (Godot et al., 2007). Therefore, H4R plays a role in allergy by mediating the recruitment of cells to the site of allergic inflammation and also by controlling this last effect together with H1R. It has recently been demonstrated that in a mouse model of allergic pruritus, the H4R antagonist JNJ7777120 is more effective in reducing the response to histamine release than H1R antagonist (Dunford et al., 2007). It is foreseen that combinatorial therapy with both H4R antagonists - when available for human use - to target mostly MC and eosinophils and H1R antagonists could be a potent new therapy for some allergic responses rather than just H1R antagonists.

\section{SEROTONIN RECEPTORS (5HTRs)}

Serotonin is a neurotransmitter that can modulate a number of functions also outside the neural system (Berger et al., 2009). Serotonin receptors, also known as 5-hydroxytryptamine receptors (5HTRs), are classified in humans into seven main families with an additional subtype for two of the families (IUPHAR Receptor Database, 2008). Although 5HTRs have been known for a long time they have only recently been characterized on MC. With the exception of the 5HTR3, a ligand gated ion channel, all other serotonin receptors are GPCRs (Ritter et al., 2012) that activate an intracellular second messenger cascade to produce an excitatory or inhibitory response.

5HT1AR is negatively coupled to adenyl cyclase via $\mathrm{Gi}$ and it is expressed on hMC (Kushnir-Sukhov et al., 2006; Ritter et al., 2012) and mBMMC (Kushnir-Sukhov et al., 2006). It is expressed on MC in normal skin and its activation induces inflammation, due to $\mathrm{MC}$ migration and adherence in the site of inflammation, but it does not involve degranulation (Nordlind et al., 2008). Even though a still controversial issue, hMC were found to be able to secrete 
serotonin both in IgE-dependent and independent manner (Askenase et al., 1991; Matsuda et al., 1995). This was further shown to activate effector T cells and macrophages (Young and Matthews, 1995), and also could show the possibility of an autocrine regulation of the MC. 5HT/5HT1AR are involved in allergic contact eczema, atopic eczema, psoriasis (Nordlind et al., 2008), and also expressed in human mastocytosis (Ritter et al., 2012).

\section{PURINERGIC RECEPTORS AND ATP-HYDROLYZING ENZYMES PURINERGIC RECEPTORS}

Purinergic receptors, also known as purinoceptors, are a family of plasma membrane molecules involved in several cellular functions such as vascular reactivity, apoptosis, and cytokines secretion. The term, purinergic receptor was originally introduced to illustrate specific classes of membrane receptors that mediate relaxation of gut smooth muscle as a response to the release of Adenosine $5^{\prime}$ triphosphate (ATP) - P2R receptors or adenosine - P1R (King and Burnstock, 2002). There are three known distinct classes of purinergic receptors, referred to as $\mathrm{P} 1, \mathrm{P} 2 \mathrm{X}$, and $\mathrm{P} 2 \mathrm{Y}$ receptors comprehending different subtypes (Bulanova and Bulfone-Paus, 2010). P2Y receptors, in addition to ATP, respond also to different nucleotides (ADP, UDP, UTP, UDP, and UDP-glucose). P1 and $\mathrm{P} 2 \mathrm{Y}$ are GPCRs whereas $\mathrm{P} 2 \mathrm{X}$ is a ligand gated ion channel.

Mast cells from most species express P1Rs: $A_{1}, A_{2 A}, A_{2 B}$, and $A_{3}$ adenosine receptors (Hua et al., 2011). Additionally they express a large variety of $\mathrm{P} 2 \mathrm{R}$. hCBMC, for example, express $\mathrm{P} 2 \mathrm{X}_{1}, \mathrm{P} 2 \mathrm{X}_{4}$, $\mathrm{P}_{2} \mathrm{X}_{7}, \mathrm{P}_{2} \mathrm{Y}_{1}, \mathrm{P}_{2} \mathrm{Y}_{2}$ (Bulanova and Bulfone-Paus, 2010), P2Y 12 , $\mathrm{P}_{2} \mathrm{Y}_{13}$, and $\mathrm{P} 2 \mathrm{Y}_{11}$ (Feng et al., 2004), while mBMMC (derived from C57BL/6 mice) express the mRNA of $\mathrm{P} 2 \mathrm{X}_{1-4}, \mathrm{P}_{2} \mathrm{X}_{6-7}$, and all $\mathrm{P} 2 \mathrm{Y}$ receptors with the exception of $\mathrm{P}_{2} \mathrm{Y}_{2}$. P815 mastocytoma cells (derived from DBA/2 mice) express mRNA for all P2X and P2Y receptors (Bulanova and Bulfone-Paus, 2010). Activation of P2XR leads to the formation of a non-selective cationic channel (Burnstock, 2007), that triggers the activation of a number of intracellular signaling molecules, including MAPK, which is connected to cytokine secretion and release. ATP induces purinergic receptor $\mathrm{P}_{2} \mathrm{X}_{7}$ mediated membrane permeabilization, apoptosis, and cytokine expression in murine MC (Bulanova et al., 2009).

Stimulation of P2YR generally leads to phospholipase C (PLC) activation that cleaves $\mathrm{PI}(4,5) \mathrm{P} 2$ to form IP3 and diacylglycerol, an activator of protein kinase $\mathrm{C}(\mathrm{PKC})$. Only the $\mathrm{P} 2 \mathrm{Y}_{11}$ receptor is directly coupled to activation of adenylate cyclase (AC) and PLC, while $\mathrm{P}_{2} \mathrm{Y}_{12}, \mathrm{P}_{2} \mathrm{Y}_{13}$, and $\mathrm{P}_{2} \mathrm{Y}_{14}$ receptors negatively affect cAMP synthesis (Van Kolen and Slegers, 2006). Extracellular nucleotides activating $\mathrm{P} 2$ receptors are involved in the regulation of $\mathrm{MC}$ degranulation. $\mathrm{P} 2 \mathrm{Y}_{13}$ receptor in a rat $\mathrm{MC}$ line $(\mathrm{RBL}-2 \mathrm{H} 3)$ activation by ADP leads to intracellular calcium mobilization and release of $\beta$-hexosaminidase. Nucleotides via $\mathrm{P}_{2} \mathrm{Y}_{2}$ mediate chemotaxis in mBMMC and CD34+ progenitors (Bulanova and Bulfone-Paus, 2010).

ATP acts as an autocrine and paracrine factor that enables the intercellular communication. MC IgE-dependent degranulation induces the release of ATP that influences the neural cells via P2X and P2Y receptors (Bulanova and Bulfone-Paus, 2010).

A study recently reported by Yip et al. showed a biphasic effect of adenosine in hCBMCs, implicating the $\mathrm{A}_{1} \mathrm{R}$ in potentiation, and $\mathrm{A}_{2} \mathrm{BR}$ receptor in the inhibition of anti-IgE-induced degranulation
(Yip et al., 2009; Hua et al., 2011). Interestingly, also leukotriene $\mathrm{E} 4$ acts as ligand for $\mathrm{P}_{2} \mathrm{Y}_{12}$ in LAD-2 cells. In addition it can induce purinergic receptor mediated pulmonary inflammation in mice (Paruchuri et al., 2009). It has been shown that adenosine binding to P1R on airway smooth muscle, goblet cells, MC, and neurons contributes to the pathogenesis of asthma (Okayama et al., 2008; Vieira et al., 2011). Adenosine inhibits and potentiates IgE-dependent histamine release from human lung MCs by an $\mathrm{A}_{2}$-purinoceptor mediated mechanism (Hughes et al., 1984).

Xanthine derived drugs such as theophylline that have been widely used for asthma, have been found to be both antagonists/agonists of adenosine receptors and phosphodiesterase inhibitors on MC. Several antagonists are currently available for research use, such as suramine (Gever et al., 2006). Although the purinergic receptors are well described in the nervous system, their discovery on MC is still relatively new and further research is required in order to understand their specific function and effects on these cells.

\section{CD203c}

CD203c (E-NPP3) belongs to a family of ecto-nucleotide pyrophosphatase/phosphodiesterases (E-NPPs) that catalyzes the cleavage of phosphodiester and phosphosulfate bonds of a variety of molecules, including deoxynucleotides NAD and nucleotide sugars (Buhring et al., 2004). These type II TM proteins are composed of a short N-terminal cytoplasmic domain, followed by the TM region, two somatomedin-like domains, the catalytic domain and a C-terminal endonuclease-like domain. Recently, CD203c has been defined as a novel activation-linked surface antigen on MC that is upregulated in response to IgE receptor cross-linking and is overexpressed on neoplastic MC in patients with systemic mastocytosis (Hauswirth et al., 2008). CD203c on basophils serves as a marker to diagnose various allergic diseases such as asthma (Ono et al., 2010). The expression and role of ATP-hydrolyzing enzymes for the biology of MC is still under investigation.

\section{CORTICOTROPIN-RELEASING HORMONE AND ENDOCANNABINOIDS}

Even though Corticotropin-releasing hormone (CRH) and endocannabinoids receptors have been typically described as central nervous system (CNS) receptors involved in regulation of the hypothalamic-pituitary-adrenocortical axis and in drugs response (Goeders and Guerin, 2000; Steiner and Wotjak, 2008), these receptors have also been found to be expressed on hematopoietic cells thus regulating peripheral conditions.

\section{CORTICOTRICOTROPIN RELEASING HORMONE RECEPTORS}

Corticotricotropin releasing hormone receptors (CRHRs) are GPCRs which are activated by urocortin (UCN), CRH, or substance $\mathrm{P}$ and consist of two receptors-CRH-R1 and CRH-R2, each encoded by a separate gene (Theoharides et al., 1998; Slominski et al., 2001; Asadi et al., 2012). CRHR signaling involves cAMP/PKA pathway or alternatively MAPK or intracellular calcium $\left(\mathrm{Ca}^{2+}\right) / \mathrm{PKC}$ pathways, depending on the site of activation (Grammatopoulos, 2011).

CRH-R1 is sensitive to $\beta$-arrestin-dependent signaling desensitization and internalization. Receptor endocytosis is also one of 
the mechanisms employed by CRH-R1 to induce ERK1/2 and p38 MAPK phosphorylation and activation intermediates (Markovic et al., 2008). CRH-R1 variant is expressed in a tissue-specific manner; it is present in anterior pituitary as well as in peripheral sites such as reproductive tissues (myometrium, endometrium, and chorion trophoblast cells) and MC (Nezi et al., 2010).

Corticotropin-releasing hormone is secreted under stress and activates the hypothalamic-pituitary-adrenal axis. Interestingly a similar network is found in the skin (Asadi et al., 2012). Addition of CRH to the LAD-2 (leukemia MC line cells) primed with substance $\mathrm{P}$ induces synthesis and release of IL-8, TNF, and vascular endothelial growth factor (VEGF) $24 \mathrm{~h}$ later (Asadi et al., 2012). MC activation by CRH induces gene expression of neurokinin (NK-1). The ability of CRH to activate MC may explain its pro-inflammatory actions and the pathophysiology of certain skin conditions, which are precipitated or exacerbated by stress, such as atopic dermatitis, eczema, psoriasis, and urticaria (Theoharides et al., 1998). CRH has pro-inflammatory actions not only on its own, but also by augmenting the expression of the respective receptors on human skin MC (Asadi et al., 2012).

\section{ENDOCANNABINOIDS RECEPTORS}

The cannabinoid receptors are a class of cell membrane receptors belonging to the GPCRs superfamily. They contain seven TM spanning domains and are divided into two subtypes, termed cannabinoid 1 (CB1) and cannabinoid 2 (CB2). The endocannabinoid system has been recognized as a major neuromodulatory system, which functions to maintain brain homeostasis (Steiner and Wotjak, 2008). The CB1 receptor is expressed mainly in the brain CNS, but also in the lungs, liver, and kidneys. The CB2 receptor is expressed mainly in the immune system and in hematopoietic cells (Pacher and Mechoulam, 2011).

CB1 was found to be expressed on human skin MC (Sugawara et al., 2012) and be activated by endocannabinoids such as anandamide (AEA) and 2-arachidonoylglycerol. CB1 and CB2 receptors can induce inhibition of adenylate cyclase activity and phosphorylation with activation of p42/p44 MAPK, p38 MAPK, and JNK as signaling pathways to regulate nuclear transcription factors. The $\mathrm{CB} 1$ receptor regulates $\mathrm{K}^{+}$and $\mathrm{Ca}^{2+}$ ion channels, probably via Go/i (Howlett, 2005). A common role of CB1 and $\mathrm{CB} 2$ receptors appears to be the modulation of ongoing release of chemical messengers. The activation of $\mathrm{CB} 2$ receptors on $\mathrm{MC}$ has direct anti-inflammatory effects due to a decrease in mediators released from the cells (Pini et al., 2012).

The best CB2-selective agonists that have been developed so far include L-759633, L-759656, and JWH-133, all structural analogs of D9-THC. Other notable examples are the non-classical cannabinoid, HU-308, and the aminoalkylindole, AM1241 (Pertwee, 2006). The activation of CB1 receptor on bronchial nerve ending has a bronchodilatory effect (Pini et al., 2012). However, inhibiting the enzymatic inactivation of pharmacologically active endogenous molecules that do not serve as endocannabinoids or causing an accumulation of endocannabinoid molecules at nonCB1, non-CB2 targets such as the TRPV1 receptor or the putative abnormal-cannabidiol receptor, might lead to adverse effects.

Endocannabinoids limit excessive MC maturation and activation in human skin in situ and regulate SCF expression, by increasing its production in human hair follicle epithelium via CB1 stimulation (Sugawara et al., 2012). On the other hand in the ovalbumin induced lung sensitization model in CB1 and CB2 deficient mice a reduction in IgE production and attenuation of bronchoalveolar lavage fluid neutrophilia was described (Kaplan et al., 2010). In some studies, activation of CB1R seems to inhibit the allergic inflammation, while in others it is still controversial. Either way, we can conclude that CB1R activation is a potential target to be used in the treatment of allergy, although further research is still required.

\section{RECEPTORS CROSS-TALK}

Cross-talk between receptors might result in co-activation or in inhibition of cell response. Co-stimulation is often required for the development of an effective immune response, and has been recognized to participate in antigen-specific signal from lymphocytes antigen receptors. In the last few years, parallel to the identification of the new MC receptors, some cross-talk effects between receptors were described, resulting either in co-activation (synergism or additive effects) or in inhibition. Most of the works have dealt with the FceRI mediated MC activation. For example IL-18R, IL33R, TSLP, and TLRs were found to work via the same signaling pathway which activates MyD88, IRAK, TRAF, and MAPK and NF-kB (Figure 1). GPCRs on MC can also co-interact to produce different responses.

\section{CO-STIMULATION}

Due to co-stimulation and cross-talk significance in modulation of MC activity, we chose to review some recent examples of this phenomenon. CCRs are known stimulatory and co-stimulatory molecules expressed on MC. Fifadara et al. showed for the first time the formation of cytoneme-like cellular extensions by BMMC, a totally new feature of these cells, upon co-stimulation of FceRI and CCR1 with antigen and CCR1 ligand, macrophage inflammatory protein- $1 \alpha$. This co-stimulation was more effective in some morphology changes and mediator release than FceRI stimulation alone (Fifadara et al., 2010). Thus, CCR can contribute to the inflammatory and allergic responses by formation of cytonemes, as a way to communicate between MC and other cells. Recently, the same group has identified 32 genes that were differentially regulated by a co-stimulation of antigen and the CCR1 ligand CCL3, compared to stimulation with antigen or CCL3 alone, in RBL-CCR1 transfected cells. Four genes were mostly up regulated $3 \mathrm{~h}$ post co-stimulation (Ccl7, Rgs1, Emp1, RT1-S3), but only the CCL7 protein was expressed at a higher level $24 \mathrm{~h}$ following costimulation. Among chemokines and cytokines tested, only CCL2 protein showed higher expression levels and IL-6 was seen only after co-stimulation, although in a very low level (Aye et al., 2012). The authors suggested therefore that CCL2, CCL7, and IL-6 may be important for $\mathrm{MC}$ regulation in the late phase of the allergic response.

Another novel example of co-stimulation is the one between FceRI and adenosine receptor. Nunomura et al. showed that costimulation of a low antigen dose together with adenosine can induce MC degranulation in a synergistic way, through cooperation of the two receptors mediated signaling. This was suggested to be relevant to the immediate asthma response upon bronchial 

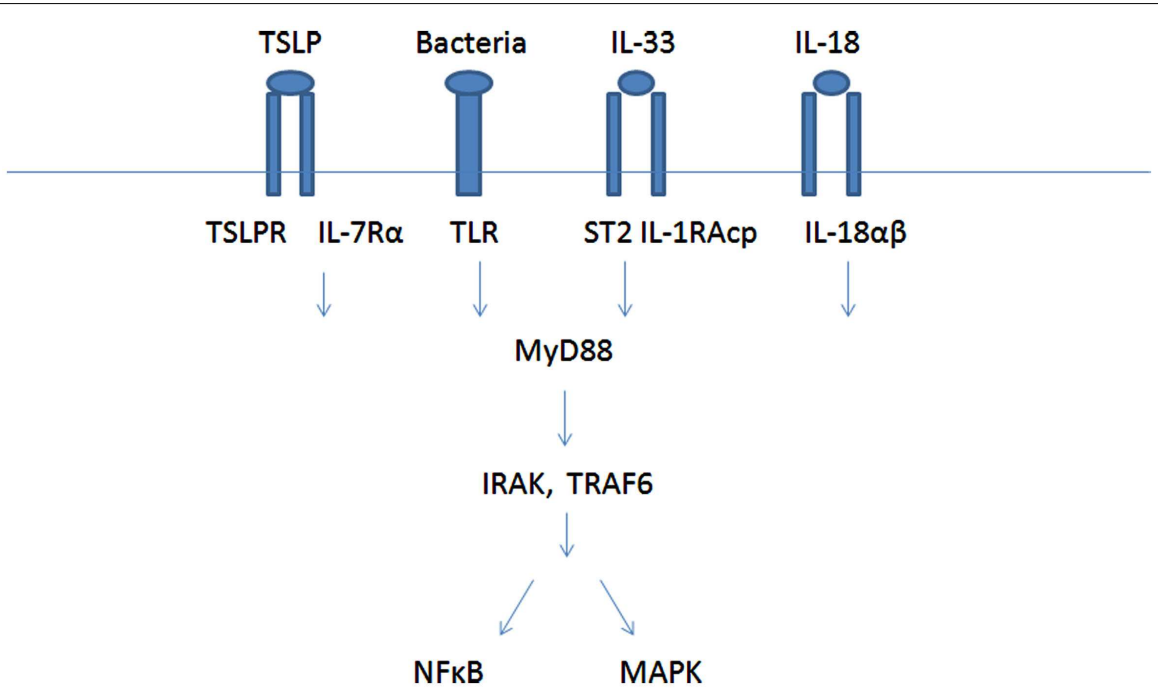

FIGURE 1 | Mast cells co-activation by IL-18, IL-33, TSLP, and TLR receptors.

challenge with low-dose allergen (Nunomura et al., 2010). It has also been shown that mBMMC mutant in the FceRI $\beta$-chain-ITAM could not be degranulated upon co-stimulation, through PI3Ksignaling pathway (Nunomura et al., 2010). These findings can provide more detailed insight to which and how specific parts of the $\beta$ chain and the PI3K-signaling are important for MC co-activation.

In mouse $\mathrm{MC}$, thrombin, a serine protease, by binding to the protease-activated receptor (PAR)-1 TRAP(14) induces the secretion of IL- 6 in a dose dependent fashion, but not of TNF $\alpha$. Co-stimulation of low level thrombin with an allergen, can synergistically enhance IL-6 secretion through FceRI signaling and the PI(3) and sphingosine-kinase pathways (Gordon et al., 2000).

Drube et al. reported a cross-activation of IL-33R and c-kit receptor in human and murine $\mathrm{MC}$, after joining of IL-33R upon ligand binding, to a constitutively bound complex composed of c-kit and IL-1R accessory protein. In primary MC, the c-kit ligand SCF, is necessary for IL-33 induced cytokine production (Drube et al., 2010). Silver et al. showed that IL-33 in HMC-1 cells induced a synergistic activation effect together with adenosine, C5a, SCF, and NGF receptors. In primary hMC, IL-33R was also synergized with FceRI activation (Silver et al., 2010).

CD48 was found to be a co-stimulatory receptor for inducing different effects in various hematopoietic cells by binding several ligands (Elishmereni and Levi-Schaffer, 2011). We have recently found that hCBMC and eosinophils can be directly activated by CD48 ligand/s (Elishmereni et al., 2011). In addition we detected some co-stimulatory effects when CBMC were activated by IgEdependent mechanisms (Minai-Fleminger, Y., Levi-Schaffer, F., unpublished data).

CD84 is a self binding receptor from the signaling lymphocyte activating molecules (SLAM) family. However it was shown on transfected RBL-2H3 cells to inhibit FceRI degranulation (OliverVila et al., 2008). Additionally CD84 was found to be expressed on hMC (Alvarez-Errico et al., 2011), and shown to be tyrosine phosphorylated upon co-stimulation with FceRI. This led to reduction in granule release and in the release of IL- 8 and GM-CSF in LAD-2 cells and human CD34+ derived MC (Alvarez-Errico et al., 2011).

As reported in the past by our group, MC express DNAX accessory molecule 1 (DNAM-1, CD226) and eosinophils express its ligand Nectin-2 (CD112). It was shown that CD226 engagement with FceRI induces an activating synergistic effect on MC and blocking of the ligand CD112 reduced the hyperactivity caused by IgE-dependent MC activation (Bachelet et al., 2006). To conclude, these few examples of co-stimulatory responses on MC can possibly help in understanding and foreseeing the complex allergic inflammatory response and be essential for the development of new anti-allergic therapy.

\section{INHIBITORY RECEPTORS AND MC INHIBITION}

Inhibitory receptors classically described on NK (Cantoni et al., 1999; for review, see Pegram et al., 2011) comprise two main families of the Ig receptor super-family and the c-type (calcium dependent) lectin superfamily. On MC, Fc $\gamma$ RIIB, CD300, CD72, and sialic acid binding Ig-like lectins (Siglec)8, 7, etc., have been described (Karra and Levi-Schaffer, 2011). Since the Fc $\gamma$ RIIB receptor has been extensively investigated (see Daeron et al., 2008; Bruhns et al., 2009) and we discussed some receptors bringing about MC inhibition, such as $\mathrm{CB} 1$, under their respective families, here we will consider only the most newly described typical IRs.

Inhibitory receptors expressed on MC can modulate their function by inhibiting typically the signaling from receptors associated with tyrosine kinases, i.e., FceRI and c-kit (Figure 2). IRs contain immunoreceptor tyrosine based inhibition motifs (ITIMs) that down regulate the activation signals transmitted through immunoreceptor tyrosine based ligand ITAMs. The engagement of IRs suppresses cell activation by promoting dephosphorylation reactions. Upon activation of ITIM-containing receptors, tyrosine residues within the motifs become phosphorylated. This leads to the recruitment of protein phosphatases, Src homology $2(\mathrm{SH})$ domain containing protein tyrosine phosphatase-1/2 (SHP-1 and SHP-2) and lipid phosphatases SH2 domain bearing 


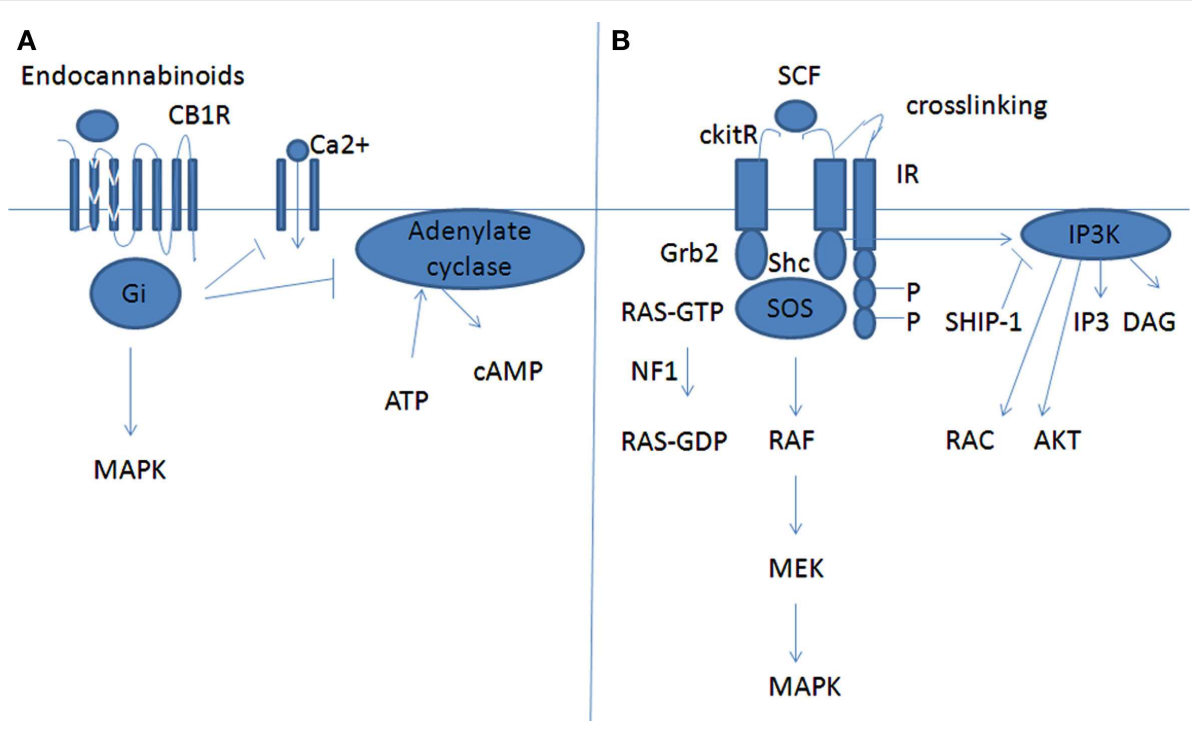

FIGURE 2 | Inhibition of MC maturation by CB1 or by a classical IR receptor. (A) CB1 inhibition effect. (B) Inhibition of C-kit mediated signaling by an inhibitory receptor (IR). Downstream molecules to CB1 or to c-kit cross-linked with the inhibitory receptor (cross-linking is mandatory to inhibitory effect).

inositol phosphatase (SHIP1). SHP-1/2 inhibits the action of tyrosine kinase, while SHIP1 terminates the PI3K-mediated pathway (Karra and Levi-Schaffer, 2011). Herewith we are going to illustrate the CD300a, Siglec 7 and 8, and CD72 IRs.

The CD300 family of myeloid immunoglobulin receptors includes activating (CD300b, CD300e) and inhibitory (CD300a, CD300f) members, as well as molecules of uncertain functions presenting a negative charge within their TM domain (CD300c, CD300d; Martinez-Barriocanal et al., 2010). None of the activating receptors identified contains a charged glutamic acid residue in the TM that is present in CD300c, suggesting that CD300c might deliver activating signals via signaling proteins other than those previously observed or that CD300c is not an activating receptor (Lankry et al., 2010). The function of CD300d is related to the regulation of the expression of other CD300 molecules and the composition of CD300 complexes on the cell surface (Comas-Casellas et al., 2012).

The CD300 IR are type I TM glycoproteins with a single IgVlike extracellular domain and a membrane proximal region, a TM region, and a cytoplasmic region with ITIM motif (Lankry et al., 2010). The cytoplasmic domains of CD300a and CD300f contain internalization motifs and the cell surface expression of these molecules might be regulated, in part, by internalization (Clark et al., 2009). The expression of CD300a and CD300f was shown in MC (Clark et al., 2009), where CD300a presents on MC from nasal polyps, lungs, and on hCBMC (Bachelet et al., 2005) and its mouse ortholog LMIR-1, is expressed on mBMMC (Kumagai et al., 2003). CD300a is also expressed on NK, T cell subsets, neutrophils, eosinophils, monocytes DC, and more recently it has been characterized on basophils (Cantoni et al., 1999; Bachelet et al., 2005; Munitz et al., 2006a; Alvarez et al., 2008; Sabato et al., 2012).

It has been recently reported that CD300a interacts with polar lipids, including the major phospholipids of cell membranes, and is able to transduce intracellular signals after lipid binding. One of CD300a ligands is phosphatidylserine which directly binds CD300a and phosphorylates ITIM in the cytoplasmic portion of CD300a on BMMC (Nakahashi-Oda et al., 2012). Interestingly, Simhadri showed that CD300a phosphatidylethanolamine and phosphatidylserine bind to CD300a, and modulate the phagocytosis of dead cells. CD300a down regulates the uptake of apoptotic cells by macrophages and its ectopic expression in CD300anegative cell lines also decreased the engulfment of dead cells (Simhadri et al., 2012). Using a co-transfection assay on THP-1 cells, Kim et al. (2012) showed that while CD300a blocked only MyD88 induced events, CD300f blocked both MyD88 and TRIF.

CD300a reduced survival of MC and eosinophils by decreasing the effect of c-kit on MC, and the IL-5, GM-CSF effect on eosinophils (Bachelet et al., 2005, 2008). Moreover a bi-specific $\mathrm{Ab}$ to $\mathrm{CD} 300 \mathrm{a}$ and IgE inhibited acute airway inflammation in an experimental asthma mouse model and passive cutaneous anaphylaxis (Bachelet et al., 2008). Also a bi-specific Ab against CD300a and CCR3 inhibited chronic airway inflammation in murine asthma, possibly by its binding on both MC and eosinophils and their consequent inhibition (Munitz et al., 2006b). Disease-wise there is evidence for alterations in the expression and function of the CD300 family in patients with psoriasis (Clark et al., 2009).

Siglec-8 appears on hMCs at the same time as other MC markers such as FceRI (Karra et al., 2009). When cross-linked by mAbs on hpbMC, Siglec-8 does not lead to apoptosis as it does on eosinophils, but rather to strong inhibition of histamine and prostaglandin D2 secretion and of $\left[\mathrm{Ca}^{2+}\right]$ influx (Yokoi et al., 2008; Bochner, 2009; Karra et al., 2009). Siglec-8 is known to specifically recognize the sialoside sequence $6^{\prime}$-sulfo-sLex (Tateno et al., 2005). Siglec- 8 has been shown to be associated with asthma (Gao et al., 2010). We have found Siglec 7, another lectinbinding IR, that was previously described on eosinophils (Munitz et al., 2006a) to be expressed and functional on hMC (Mizrahi, 
S., Karra, L., Ben Zimra, M., and Levi-Schaffer, F., unpublished data).

CD72 (Lyb-2) is an ITIM-containing $45 \mathrm{kDa}$ type II TM protein of the C-type lectin family (Wu and Bondada, 2009) whose natural ligands have been identified as CD100 or Semaphorin 4D (Sema4D). CD72, which is considered to be an important coreceptor regulating B-cell activation (Wu and Bondada, 2009), is also expressed on mouse NK cells (Alcon et al., 2009) and on hPBMC and human cell lines (Kataoka et al., 2010). Ligation of CD72 reduced SCF-mediated proliferation, chemotaxis, and MCP-1 (or CCL2) production in hMCs and the suppression of growth of HMC-1.2 harboring the gain-of-function mutation in KIT gene (Kataoka et al., 2010).

In conclusion IR, that have been shown to mostly modulate on MC the activation of FceRI and c-kit, may have by themselves or by cooperation with other receptors, inhibitory functions on other receptors not necessarily linked to tyrosine kinases mechanism, although this still has to be thoroughly investigated.

\section{REFERENCES}

Akdis, M., Burgler, S., Crameri, R., Eiwegger, T., Fujita, H., Gomez, E., Klunker, S., Meyer, N., O’Mahony, L., Palomares, O., Rhyner, C., Ouaked, N., Schaffartzik, A., van de Veen, W., Zeller, S., Zimmermann, M., and Akdis, C. A. (2011). Interleukins, from 1 to 37, and interferon-gamma: receptors, functions, and roles in diseases. J. Allergy Clin. Immunol. 127, 701-721 e701-e770.

Akira, S., and Takeda, K. (2004). Tolllike receptor signalling. Nat. Rev. Immunol. 4, 499-511.

Alcon, V. L., Luther, C., Balce, D., and Takei, F. (2009). B-cell co-receptor CD72 is expressed on NK cells and inhibits IFN-gamma production but not cytotoxicity. Eur. J. Immunol. 39, 826-832.

Allakhverdi, Z., Comeau, M. R., Jessup, H. K., Yoon, B. R., Brewer, A., Chartier, S., Paquette, N., Ziegler, S. F., Sarfati, M., and Delespesse, G. (2007). Thymic stromal lymphopoietin is released by human epithelial cells in response to microbes, trauma, or inflammation and potently activates mast cells. J. Exp. Med. 204, 253-258.

Altinova, A. E., Yetkin, I., Akbay, E., Bukan, N., and Arslan, M. (2008). Serum IL-18 levels in patients with type 1 diabetes: relations to metabolic control and microvascular complications. Cytokine 42, 217-221.

Alvarez, Y., Tang, X., Coligan, J. E., and Borrego, F. (2008). The CD300a (IRp60) inhibitory receptor is rapidly up-regulated on human neutrophils in response to inflammatory stimuli and modulates
CD32a (FcgammaRIIa) mediated signaling. Mol. Immunol. 45, 253-258.

Alvarez-Errico, D., Oliver-Vila, I., Ainsua-Enrich, E., Gilfillan, A. M., Picado, C., Sayos, J., and Martin, M. (2011). CD84 negatively regulates IgE high-affinity receptor signaling in human mast cells. J. Immunol. 187, 5577-5586.

Arend, W. P., Palmer, G., and Gabay, C. (2008). IL-1, IL-18, and IL-33 families of cytokines. Immunol. Rev. 223, 20-38.

Asadi, S., Alysandratos, K. D., Angelidou, A., Miniati, A., Sismanopoulos, N., Vasiadi, M., Zhang, B., Kalogeromitros, D., and Theoharides, T. C. (2012). Substance P (SP) induces expression of functional corticotropin-releasing hormone receptor-1 (CRHR-1) in human mast cells. J. Invest. Dermatol. 132, 324-329.

Askenase, P. W., Herzog, W. R., Millet, I., Paliwal, V., Ramabhadran, R., Rochester, C., Geba, G. P., and Ptak, W. (1991). Serotonin initiation of delayed-type hypersensitivity: mediation by a primitive Thy-1+ antigen-specific clone or by specific monoclonal IgE antibody. Skin Pharmacol. 4(Suppl. 1), 25-42.

Aye, C. C., Toda, M., Morohoshi, K., and Ono, S. J. (2012). Identification of genes and proteins specifically regulated by costimulation of mast cell Fcepsilon receptor I and chemokine receptor 1. Exp. Mol. Pathol. 92, 267-274.

Bachelet, I., Munitz, A., Berent-Maoz, B., Mankuta, D., and Levi-Schaffer, F. (2008). Suppression of normal

\section{CONCLUSION}

Mast cells express a variety of receptors that enable them, both in activating or inhibiting ways, to modulate immune response and can be used as treatment targets in disease conditions. While with some of the described receptors such as $\mathrm{H} 4$ and purinergic receptors, we are close to developing a drug, with others, such as TSLP, more basic studies on their functions are needed. Overall, evidences show that MC receptors have a strong therapeutic potential but still a better understanding of their pathophysiological roles, expression and their role in the immune system is required in order to develop effective and side effect free therapeutic interventions in the near future.

\section{ACKNOWLEDGMENTS}

This work was supported by COST (European Cooperation in Science and Technology) Action BM1007 (Mast Cells and Basophils - Targets for Innovative Therapies) of the European Community.

and malignant kit signaling by a bispecific antibody linking kit with CD300a. J. Immunol. 180, 6064-6069.

Bachelet, I., Munitz, A., Mankutad, D., and Levi-Schaffer, F. (2006). Mast cell costimulation by CD226/CD112 (DNAM-1/Nectin-2): a novel interface in the allergic process. J. Biol. Chem. 281, 27190-27196.

Bachelet, I., Munitz, A., Moretta, A., Moretta, L., and Levi-Schaffer, F. (2005). The inhibitory receptor IRp60 (CD300a) is expressed and functional on human mast cells. $J$. Immunol. 175, 7989-7995.

Baslund, B., Tvede, N., DanneskioldSamsoe, B., Larsson, P., Panayi, G. Petersen, J., Petersen, L. J., Beurskens, F. J., Schuurman, J., van de Winkel, J. G., Parren, P. W., Gracie, J. A., Jongbloed, S., Liew, F. Y., and Mcinnes, I. B. (2005). Targeting interleukin-15 in patients with rheumatoid arthritis: a proof-of-concept study. Arthritis Rheum. 52, 2686-2692.

Berger, M., Gray, J. A., and Roth, B. L. (2009). The expanded biology of serotonin. Annu. Rev. Med. 60, 355-366.

Bochner, B. S. (2009). Siglec-8 on human eosinophils and mast cells, and Siglec-F on murine eosinophils, are functionally related inhibitory receptors. Clin. Exp. Allergy 39, 317-324.

Brightling, C. E., Kaur, D., Berger, P., Morgan, A. J., Wardlaw, A. J., and Bradding, P. (2005). Differential expression of CCR3 and CXCR3 by human lung and bone marrowderived mast cells: implications for tissue mast cell migration. J. Leukoc. Biol. 77, 759-766.
Bruhns, P., Iannascoli, B., England, P., Mancardi, D. A., Fernandez, N., Jorieux, S., and Daeron, M. (2009). Specificity and affinity of human Fcgamma receptors and their polymorphic variants for human IgG subclasses. Blood 113, 3716-3725.

Buhring, H. J., Streble, A., and Valent, P. (2004). The basophil-specific ectoenzyme E-NPP3 (CD203c) as a marker for cell activation and allergy diagnosis. Int. Arch. Allergy Immunol. 133, 317-329.

Bulanova, E., Budagian, V., Orinska, Z., Koch-Nolte, F., Haag, F., and Bulfone-Paus, S. (2009). ATP induces $\mathrm{P} 2 \mathrm{X} 7$ receptor-independent cytokine and chemokine expression through $\mathrm{P} 2 \mathrm{X} 1$ and $\mathrm{P} 2 \mathrm{X} 3$ receptors in murine mast cells. J. Leukoc. Biol. 85, 692-702.

Bulanova, E., and Bulfone-Paus, S. (2010). P2 receptor-mediated signaling in mast cell biology. Purinergic Signal. 6, 3-17.

Burnstock, G. (2007). Purine and pyrimidine receptors. Cell. Mol. Life Sci. 64, 1471-1483.

Cantoni, C., Bottino, C., Augugliaro, R., Morelli, L., Marcenaro, E., Castriconi, R., Vitale, M., Pende, D., Sivori, S., Millo, R., Biassoni, R., Moretta, L., and Moretta, A. (1999). Molecular and functional characterization of IRp60, a member of the immunoglobulin superfamily that functions as an inhibitory receptor in human NK cells. Eur. J. Immunol. 29, 3148-3159.

Cevikbas, F., and Steinhoff, M. (2012). IL-33: a novel danger signal system in atopic dermatitis. J. Invest. Dermatol. 132, 1326-1329. 
Clark, G. J., Ju, X., Tate, C., and Hart, D. N. (2009). The CD300 family of molecules are evolutionarily significant regulators of leukocyte functions. Trends Immunol. 30, 209-217.

Colucci, F. (2007). Unexpected partnership between IL-15 and DAP10. Nat. Immunol. 8, 1289-1291.

Comas-Casellas, E., MartinezBarriocanal, A., Miro, F., Ejarque-Ortiz, A., Schwartz, S. Jr., Martin, M., and Sayos, J. (2012). Cloning and characterization of CD300d, a novel member of the human CD300 family of immune receptors. J. Biol. Chem. 287, 9682-9693.

Comeau, M. R., and Ziegler, S. F. (2010). The influence of TSLP on the allergic response. Mucosal Immunol. 3, 138-147.

Corrigan, C. J., Jayaratnam, A., Wang, Y., Liu, Y., de Waal Malefyt, R., Meng, Q., Kay, A. B., Phipps, S., Lee, T. H., and Ying, S. (2009). Early production of thymic stromal lymphopoietin precedes infiltration of dendritic cells expressing its receptor in allergen-induced late phase cutaneous responses in atopic subjects. Allergy 64, 1014-1022.

Daeron, M., Jaeger, S., Du Pasquier, L., and Vivier, E. (2008). Immunoreceptor tyrosine-based inhibition motifs: a quest in the past and future. Immunol. Rev. 224, 11-43.

Drube, S., Heink, S., Walter, S., Lohn, T., Grusser, M., Gerbaulet, A., Berod, L., Schons, J., Dudeck, A., Freitag, J., Grotha, S., Reich, D., Rudeschko, O., Norgauer, J., Hartmann, K., Roers, A., and Kamradt, T. (2010). The receptor tyrosine kinase c-Kit controls IL-33 receptor signaling in mast cells. Blood 115, 3899-3906.

Dunford, P. J., Williams, K. N., Desai, P. J., Karlsson, L., Mcqueen, D., and Thurmond, R. L. (2007). Histamine $\mathrm{H} 4$ receptor antagonists are superior to traditional antihistamines in the attenuation of experimental pruritus. J. Allergy Clin. Immunol. 119, 176-183.

Edwards, M. J. (2008). Therapy directed against thymic stromal lymphopoietin. Drug News Perspect. 21, 312-316.

Elishmereni, M., Alenius, H. T., Bradding, P., Mizrahi, S., Shikotra, A., Minai-Fleminger, Y., Mankuta, D., Eliashar, R., Zabucchi, G., and Levi-Schaffer, F. (2011). Physical interactions between mast cells and eosinophils: a novel mechanism enhancing eosinophil survival in vitro. Allergy 66, 376-385.

Elishmereni, M., and Levi-Schaffer, F. (2011). CD48: a co-stimulatory receptor of immunity. Int. J. Biochem. Cell Biol. 43, 25-28.

Fang, C., Siew, L. Q., Corrigan, C. J., and Ying, S. (2010). The role of thymic stromal lymphopoietin in allergic inflammation and chronic obstructive pulmonary disease. Arch. Immunol. Ther. Exp. (Warsz.) 58, 81-90.

Feng, C., Mery, A. G., Beller, E. M., Favot, C., and Boyce, J. A. (2004). Adenine nucleotides inhibit cytokine generation by human mast cells through a Gs-coupled receptor. J. Immunol. 173, 7539-7547.

Fifadara, N. H., Beer, F., Ono, S. and Ono, S. J. (2010). Interaction between activated chemokine receptor 1 and FcepsilonRI at membrane rafts promotes communication and F-actin-rich cytoneme extensions between mast cells. Int. Immunol. 22, 113-128.

Forsythe, P., and Ennis, M. (1999). Adenosine, mast cells and asthma. Inflamm. Res. 48, 301-307.

Francis, H. L., Demorrow, S., Franchitto, A., Venter, J. K., Mancinelli, R. A., White, M. A., Meng, F., Ueno, Y., Carpino, G., Renzi, A., Baker, K. K., Shine, H. E., Francis, T. C., Gaudio, E., Alpini, G. D., and Onori, P. (2012). Histamine stimulates the proliferation of small and large cholangiocytes by activation of both $\mathrm{IP}(3) / \mathrm{Ca}(2$ () and cAMP-dependent signaling mechanisms. Lab. Invest. 92, 282-294.

Gao, P. S., Shimizu, K., Grant, A. V., Rafaels, N., Zhou, L. F., Hudson, S. A., Konno, S., Zimmermann, N., Araujo, M. I., Ponte, E. V., Cruz, A. A., Nishimura, M., Su, S. N., Hizawa, N., Beaty, T. H., Mathias, R. A., Rothenberg, M. E., Barnes, K. C., and Bochner, B. S. (2010). Polymorphisms in the sialic acid-binding immunoglobulin-like lectin-8 (Siglec-8) gene are associated with susceptibility to asthma. Eur. J. Hum. Genet. 18, 713-719.

Gever, J. R., Cockayne, D. A., Dillon, M. P., Burnstock, G., and Ford, A. P. (2006). Pharmacology of P2X channels. Pflugers Arch. 452, 513-537.

Gibbs, B. F., and Levi-Schaffer, F. (2012). $\mathrm{H} 4$ receptors in mast cells and basophils: a new therapeutic target for allergy? Front. Biosci. 17, 430-437.

Godfrey, W. R., Fagnoni, F. F., Harara, M. A., Buck, D., and Engleman, E. G. (1994). Identification of a human OX-40 ligand, a costimulator of CD4+ T cells with homology to tumor necrosis factor. J. Exp. Med. 180, 757-762.
Godot, V., Arock, M., Garcia, G., Capel, F., Flys, C., Dy, M., Emilie, D., and Humbert, M. (2007). H4 histamine receptor mediates optimal migration of mast cell precursors to CXCL12. J. Allergy Clin. Immunol. 120, 827-834.

Goeders, N. E., and Guerin, G. F. (2000). Effects of the CRH receptor antagonist CP-154,526 on intravenous cocaine self-administration in rats. Neuropsychopharmacology 23, 577-586.

Gordon, J. R., Zhang, X., Stevenson, K., and Cosford, K. (2000). Thrombin induces IL-6 but not TNFalpha secretion by mouse mast cells: threshold-level thrombin receptor and very low level FcepsilonRI signaling synergistically enhance IL6 secretion. Cell. Immunol. 205, 128-135.

Gracie, J. A., Forsey, R. J., Chan, W. L., Gilmour, A., Leung, B. P., Greer, M. R., Kennedy, K., Carter, R., Wei, X. Q., Xu, D., Field, M., Foulis, A., Liew, F. Y., and Mcinnes, I. B. (1999). A proinflammatory role for IL-18 in rheumatoid arthritis. J. Clin. Invest. 104, 1393-1401.

Grammatopoulos, D. K. (2011) Insights into mechanisms of corticotropin-releasing hormone receptor signal transduction. $\mathrm{Br}$. J. Pharmacol. 166, 85-97.

Gri, G., Piconese, S., Frossi, B., Manfroi, V., Merluzzi, S., Tripodo, C., Viola, A., Odom, S., Rivera, J., Colombo, M. P., and Pucillo, C. E. (2008). CD4+CD25+ regulatory $\mathrm{T}$ cells suppress mast cell degranulation and allergic responses through OX40OX40L interaction. Immunity 29 771-781.

Harada, M., Obara, K., Hirota, T. Yoshimoto, T., Hitomi, Y., Sakashita, M., Doi, S., Miyatake, A., Fujita, K., Enomoto, T., Taniguchi, M., Higashi, N., Fukutomi, Y., Nakanishi, K., Nakamura, Y., and Tamari, M. (2009). A functional polymorphism in IL-18 is associated with severity of bronchial asthma. Am. J. Respir. Crit. Care Med. 180, 1048-1055.

Hauswirth, A. W., Escribano, L., Prados, A., Nunez, R., Mirkina, I., Kneidinger, M., Florian, S., Sonneck, K., Vales, A., Schernthaner, G. H., Sanchez-Munoz, L., Sperr, W. R., Buhring, H. J., Orfao, A., and Valent, P. (2008). CD203c is overexpressed on neoplastic mast cells in systemic mastocytosis and is upregulated upon $\operatorname{IgE}$ receptor cross-linking. Int. J. Immunopathol. Pharmacol. 21, 797-806.

He, R., and Geha, R. S. (2010). Thymic stromal lymphopoietin.
Ann. N. Y. Acad. Sci. 1183, 13-24.

Helmby, H., and Grencis, R. K. (2002). IL-18 regulates intestinal mastocytosis and Th2 cytokine production independently of IFN-gamma during Trichinella spiralis infection. $J$. Immunol. 169, 2553-2560.

Hofstra, C. L., Desai, P. J., Thurmond, R. L., and Fung-Leung, W. P. (2003). Histamine $\mathrm{H} 4$ receptor mediates chemotaxis and calcium mobilization of mast cells. J. Pharmacol. Exp. Ther. 305, 1212-1221.

Homey, B., and Bunemann, E. (2004). Chemokines and inflammatory skin diseases. Ernst Schering Res. Found. Workshop 45, 69-83.

Homey, B., Meller, S., Savinko, T., Alenius, H., and Lauerma, A. (2007). Modulation of chemokines by staphylococcal superantigen in atopic dermatitis. Chem. Immunol. Allergy 93, 181-194.

Homey, B., Steinhoff, M., Ruzicka, T., and Leung, D. Y. (2006). Cytokines and chemokines orchestrate atopic skin inflammation. J. Allergy Clin. Immunol. 118, 178-189.

Howlett, A. C. (2005). Cannabinoid receptor signaling. Handb. Exp. Pharmacol. 168, 53-79.

Hsu, C. L., Neilsen, C. V., and Bryce, P. J. (2010). IL-33 is produced by mast cells and regulates IgE-dependent inflammation. PLoS ONE 5, e11944. doi:10.1371/journal.pone.0011944

Hua, X., Chason, K. D., Patel, J. Y., Naselsky, W. C., and Tilley, S. L. (2011). IL-4 amplifies the proinflammatory effect of adenosine in human mast cells by changing expression levels of adenosine receptors. PLOS ONE 6, e24947. doi:10.1371/journal.pone.0024947

Hueber, A. J., Alves-Filho, J. C., Asquith, D. L., Michels, C., Millar, N. L., Reilly, J. H., Graham, G. J., Liew, F. Y., Miller, A. M., and Mcinnes, I. B. (2011) IL-33 induces skin inflammation with mast cell and neutrophil activation. Eur. J. Immunol. 41, 2229-2237.

Hughes, P. J., Holgate, S. T., and Church, M. K. (1984). Adenosine inhibits and potentiates IgEdependent histamine release from human lung mast cells by an A2purinoceptor mediated mechanism. Biochem. Pharmacol. 33, 3847-3852.

Ilves, T., and Harvima, I. T. (2012). OX40 ligand and OX40 are increased in atopic dermatitis lesions but do not correlate with clinical severity. J. Eur. Acad. Dermatol. Venereol. doi: 10.1111/j.14683083.2012.04587.x. [Epub ahead of print]. 
Isaksen, D. E., Baumann, H., Zhou, B., Nivollet, S., Farr, A. G., Levin, S. D., and Ziegler, S. F. (2002). Uncoupling of proliferation and Stat 5 activation in thymic stromal lymphopoietinmediated signal transduction. J. Immunol. 168, 3288-3294.

Ishimitsu, R., Nishimura, H., Yajima, T., Watase, T., Kawauchi, H., and Yoshikai, Y. (2001). Overexpression of IL-15 in vivo enhances Tcl response, which inhibits allergic inflammation in a murine model of asthma. J. Immunol. 166, 1991-2001.

Ito, T., Wang, Y. H., Duramad, O., Hori, T., Delespesse, G. J., Watanabe, N., Qin, F. X., Yao, Z., Cao, W., and Liu, Y. J. (2005). TSLP-activated dendritic cells induce an inflammatory $\mathrm{T}$ helper type 2 cell response through OX40 ligand. J. Exp. Med. 202, 1213-1223.

IUPHAR Receptor Database. (2008). 5Hydroxytryptamine receptors. International Union of Basic and Clinical Pharmacology. Available at: www.iuphar-db.org. [accessed April 11, 2008].

Jackson, N. E., Wang, H. W., Tedla, N., Mcneil, H. P., Geczy, C. L., Collins, A., Grimm, M. C., Hampartzoumian, T., and Hunt, J. E. (2005). IL-15 induces mast cell migration via a pertussis toxin-sensitive receptor. Eur. J. Immunol. 35, 2376-2385.

Jolly, P. S., Bektas, M., Olivera, A., Gonzalez-Espinosa, C., Proia, R. L., Rivera, J., Milstien, S., and Spiegel, S. (2004). Transactivation of sphingosine-1-phosphate receptors by FcepsilonRI triggering is required for normal mast cell degranulation and chemotaxis. J. Exp. Med. 199, 959-970.

Jolly, P. S., Bektas, M., Watterson, K. R., Sankala, H., Payne, S. G., Milstien, S., and Spiegel, S. (2005). Expression of SphK1 impairs degranulation and motility of RBL-2H3 mast cells by desensitizing S1P receptors. Blood 105, 4736-4742.

Juremalm, M., and Nilsson, G. (2005). Chemokine receptor expression by mast cells. Chem. Immunol. Allergy 87, 130-144.

Juremalm, M., Olsson, N., and Nilsson, G. (2002). Selective CCL5/RANTESinduced mast cell migration through interactions with chemokine receptors CCR1 and CCR4. Biochem. Biophys. Res. Commun. 297, 480-485.

Kaplan, B. L., Lawver, J. E., Karmaus, P. W., Ngaotepprutaram, T., Birmingham, N. P., Harkema, J. R., and Kaminski, N. E. (2010). The effects of targeted deletion of cannabinoid receptors $\mathrm{CB} 1$ and $\mathrm{CB} 2$ on intranasal sensitization and challenge with adjuvant-free ovalbumin. Toxicol. Pathol. 38, 382-392.

Karni, A., Koldzic, D. N., Bharanidharan, P., Khoury, S. J., and Weiner, H. L. (2002). IL-18 is linked to raised IFN-gamma in multiple sclerosis and is induced by activated CD4(+) T cells via CD40-CD40 ligand interactions. J. Neuroimmunol. 125, 134-140.

Karra, L., Berent-Maoz, B., Ben-Zimra, M., and Levi-Schaffer, F. (2009). Are we ready to downregulate mast cells? Curr. Opin. Immunol. 21, 708-714.

Karra, L., and Levi-Schaffer, F. (2011). Down-regulation of mast cell responses through ITIM containing inhibitory receptors. Adv. Exp. Med. Biol. 716, 143-159.

Kashiwakura, J., Yokoi, H., Saito, H., and Okayama, Y. (2004). T cell proliferation by direct cross-talk between OX40 ligand on human mast cells and OX40 on human T cells: comparison of gene expression profiles between human tonsillar and lungcultured mast cells. J. Immunol. 173, 5247-5257.

Kataoka, T. R., Kumanogoh, A., Bandara, G., Metcalfe, D. D., and Gilfillan, A. M. (2010). CD72 negatively regulates KIT-mediated responses in human mast cells. J. Immunol. 184, 2468-2475.

Kim, E. J., Lee, S. M., Suk, K., and Lee, W. H. (2012). CD300a and CD300f differentially regulate the MyD88 and TRIF-mediated TLR signalling pathways through activation of SHP-1 and/or SHP-2 in human monocytic cell lines. Immunology 135, 226-235.

King, B. F., and Burnstock, G. (2002). "Purinergic receptors," in Understanding G Protein-Coupled Receptors and Their Role in the CNS, eds M. Pangalos and C. Davies (Oxford, Oxford University Press), 422-438.

Knisz, J., Banks, A., Mckeag, L., Metcalfe, D. D., Rothman, P. B., and Brown, J. M. (2009). Loss of SOCS7 in mice results in severe cutaneous disease and increased mast cell activation. Clin. Immunol. 132, 277-284.

Konishi, H., Tsutsui, H., Murakami, T., Yumikura-Futatsugi, S., Yamanaka, K., Tanaka, M., Iwakura, Y., Suzuki, N., Takeda, K., Akira, S., Nakanishi, K., and Mizutani, H. (2002). IL-18 contributes to the spontaneous development of atopic dermatitis-like inflammatory skin lesion independently of IgE/stat6 under specific pathogen-free conditions. Proc. Natl. Acad. Sci. U.S.A. 99, 11340-11345.

Kumagai, H., Oki, T., Tamitsu, K., Feng, S. Z., Ono, M., Nakajima, H., Bao, Y. C., Kawakami, Y., Nagayoshi,
K., Copeland, N. G., Gilbert, D. J., Jenkins, N. A., Kawakami, T. and Kitamura, T. (2003). Identification and characterization of a new pair of immunoglobulin-like receptors LMIR1 and 2 derived from murine bone marrow-derived mast cells. Biochem. Biophys. Res. Commun. 307, 719-729.

Kunikata, T., Torigoe, K., Ushio, S., Okura, T., Ushio, C., Yamauchi, H., Ikeda, M., Ikegami, H., and Kurimoto, M. (1998). Constitutive and induced IL-18 receptor expression by various peripheral blood cell subsets as determined by anti-hIL-18R monoclonal antibody. Cell. Immunol. 189, 135-143.

Kushnir-Sukhov, N. M., Gilfillan, A. M., Coleman, J. W., Brown, J. M. Bruening, S., Toth, M., and Metcalfe, D. D. (2006). 5-hydroxytryptamine induces mast cell adhesion and migration. J. Immunol. 177, 6422-6432.

Lacotte, S., Brun, S., Muller, S., and Dumortier, H. (2009). CXCR3, inflammation, and autoimmune diseases. Ann. N. Y. Acad. Sci. 1173 310-317.

Lankry, D., Simic, H., Klieger, Y., LeviSchaffer, F., Jonjic, S., and Mandelboim, O. (2010). Expression and function of CD300 in NK cells. $J$. Immunol. 185, 2877-2886.

Le, T. A., Takai, T., Vu, A. T., Kinoshita, H., Chen, X., Ikeda, S., Ogawa, H., and Okumura, K. (2011). Flagellin induces the expression of thymic stromal lymphopoietin in human keratinocytes via toll-like receptor 5. Int. Arch. Allergy Immunol. 155 31-37.

Levi-Schaffer, F., and Eliashar, R. (2009). Mast cell stabilizing properties of antihistamines. J. Invest. Dermatol. 129, 2549-2551.

Liew, F. Y., Pitman, N. I., and Mcinnes, I. B. (2010). Disease-associated functions of IL-33: the new kid in the IL-1 family. Nat. Rev. Immunol. 10 103-110.

Lippert, U., Artuc, M., Grutzkau, A., Babina, M., Guhl, S., Haase, I., Blaschke, V., Zachmann, K., Knosalla, M., Middel, P., KrugerKrasagakis, S., and Henz, B. M. (2004). Human skin mast cells express $\mathrm{H} 2$ and $\mathrm{H} 4$, but not $\mathrm{H} 3$ receptors. J. Invest. Dermatol. 123 116-123.

Liu, Y. J. (2007). Thymic stromal lymphopoietin and OX40 ligand pathway in the initiation of dendritic cellmediated allergic inflammation. $J$. Allergy Clin. Immunol. 120, 238-244; quiz 245-236.
Lorenzen, I., Dingley, A. J., Jacques, Y., and Grotzinger, J. (2006). The structure of the interleukin-15 alpha receptor and its implications for ligand binding. J. Biol. Chem. 281, 6642-6647.

Luther, S. A., Bidgol, A., Hargreaves, D. C., Schmidt, A., Xu, Y., Paniyadi, J., Matloubian, M., and Cyster, J. G. (2002). Differing activities of homeostatic chemokines CCL19, CCL21, and CXCL12 in lymphocyte and dendritic cell recruitment and lymphoid neogenesis. J. Immunol. 169, 424-433.

Malaviya, R., and Abraham, S. N. (2001). Mast cell modulation of immune responses to bacteria. Immunol. Rev. 179, 16-24.

Malaviya, R., Gao, Z., Thankavel, K., van der Merwe, P. A., and Abraham, S. N. (1999). The mast cell tumor necrosis factor alpha response to FimH-expressing Escherichia coli is mediated by the glycosylphosphatidylinositolanchored molecule CD48. Proc. Natl. Acad. Sci. U.S.A. 96, 8110-8115.

Markovic, D., Punn, A., Lehnert, H., and Grammatopoulos, D. K. (2008) Intracellular mechanisms regulating corticotropin-releasing hormone receptor-2beta endocytosis and interaction with extracellularly regulated kinase $1 / 2$ and p38 mitogen-activated protein kinase signaling cascades. Mol. Endocrinol. 22, 689-706.

Martinez-Barriocanal, A., ComasCasellas, E., Schwartz, S. Jr., Martin, M., and Sayos, J. (2010). CD300 heterocomplexes, a new and familyrestricted mechanism for myeloid cell signaling regulation. J. Biol. Chem. 285, 41781-41794.

Masini, E., Blandina, P., Brunelleschi, S., and Mannaioni, P. F. (1982). Evidence for H2-receptor-mediated inhibition of histamine release from isolated rat mast cells. Agents Actions 12, 85-88.

Matsuda, H., Ptak, W., and Askenase, P. W. (1995). Role of mast cells versus basophils in IgE-dependent local ear skin release of the serotonin required to initiate contact sensitivity in mice. Int. Arch. Allergy Immunol. 107, 364.

McCurdy, J. D., Lin, T. J., and Marshall, J. S. (2001). Toll-like receptor 4mediated activation of murine mast cells. J. Leukoc. Biol. 70, 977-984.

McCurdy, J. D., Olynych, T. J., Maher, L. H., and Marshall, J. S. (2003). Cutting edge: distinct Toll-like receptor 2 activators selectively induce different classes of mediator production from human mast cells. J. Immunol. 
170, 1625-1629.

Meiser, A., Mueller, A., Wise, E. L., Mcdonagh, E. M., Petit, S. J., Saran, N., Clark, P. C., Williams, T. J., and Pease, J. E. (2008). The chemokine receptor CXCR3 is degraded following internalization and is replenished at the cell surface by de novo synthesis of receptor. J. Immunol. 180, 6713-6724.

Morse, K. L., Behan, J., Laz, T. M., West, R. E. Jr., Greenfeder, S. A., Anthes, J. C., Umland, S., Wan, Y., Hipkin, R. W., Gonsiorek, W., Shin, N., Gustafson, E. L., Qiao, X., Wang, S., Hedrick, J. A., Greene, J., Bayne, M., and Monsma, F. J. Jr. (2001). Cloning and characterization of a novel human histamine receptor. J. Pharmacol. Exp. Ther. 296, 1058-1066.

Mortier, E., Woo, T., Advincula, R., Gozalo, S., and Ma, A. (2008). IL15Ralpha chaperones IL-15 to stable dendritic cell membrane complexes that activate NK cells via trans presentation. J. Exp. Med. 205, 1213-1225.

Munitz, A., Bachelet, I., Eliashar, R., Moretta, A., Moretta, L., and LeviSchaffer, F. (2006a). The inhibitory receptor IRp60 (CD300a) suppresses the effects of IL-5, GM-CSF, and eotaxin on human peripheral blood eosinophils. Blood 107, 1996-2003.

Munitz, A., Bachelet, I., and LeviSchaffer, F. (2006b). Reversal of airway inflammation and remodeling in asthma by a bispecific antibody fragment linking CCR3 to CD300a. J. Allergy Clin. Immunol. 118, 1082-1089.

Munitz, A., Bachelet, I., and LeviSchaffer, F. (2007). CD48 as a novel target in asthma therapy. Recent Pat. Inflamm. Allergy Drug Discov. 1, 9-12.

Munoz, S., Hernandez-Pando, R., Abraham, S. N., and Enciso, J. A. (2003). Mast cell activation by Mycobacterium tuberculosis: mediator release and role of CD48. J. Immunol. 170, 5590-5596.

Nakahashi-Oda, C., Tahara-Hanaoka, S., Honda, S., Shibuya, K., and Shibuya, A. (2012). Identification of phosphatidylserine as a ligand for the CD300a immunoreceptor. Biochem. Biophys. Res. Commun. 417, 646-650.

Nakanishi, K., Yoshimoto, T., Tsutsui, H., and Okamura, H. (2001). Interleukin-18 regulates both Th1 and Th2 responses. Annu. Rev. Immunol. 19, 423-474.

Nezi, M., Trianti-Dimoleni, V., and Mastorakos, G. (2010). "Corticotropinreleasing hormone $(\mathrm{CRH})$ and the immune/inflammatory response," in Adrenal Physiology and Diseases, Chap. 9, ed. G. Chrousos. Available at: www.endotext.org/adrenal/adrenal9 Nordlind, K., Azmitia, E. C., and Slominski, A. (2008). The skin as a mirror of the soul: exploring the possible roles of serotonin. Exp. Dermatol. 17, 301-311.

Novick, D., Kim, S. H., Fantuzzi, G., Reznikov, L. L., Dinarello, C. A., and Rubinstein, M. (1999). Interleukin-18 binding protein: a novel modulator of the Thl cytokine response. Immunity 10, 127-136.

Nunomura, S., Gon, Y., Yoshimaru, T., Kashiwakura, J., Kawakami, T., and Ra, C. (2010). FcepsilonRI beta-chain ITAM amplifies PI3K-signaling to ensure synergistic degranulation response via FcepsilonRI and adenosine receptors. Eur. J. Immunol. 40, 1205-1217.

Ohkubo, T., Shibata, M., Inoue, M., Kaya, H., and Takahashi, H. (1994). Autoregulation of histamine release via the histamine $\mathrm{H} 3$ receptor on mast cells in the rat skin. Arch. Int. Pharmacodyn. Ther. 328, 307-314.

Ohta, Y., Hamada, Y., and Katsuoka, K. (2001). Expression of IL-18 in psoriasis. Arch. Dermatol. Res. 293, 334-342.

Okayama, Y., Okumura, S., Sagara, H., Yuki, K., Sasaki, T., Watanabe, N., Fueki, M., Sugiyama, K., Takeda, K., Fukuda, T., Saito, H., and Ra, C. (2009). FcepsilonRI-mediated thymic stromal lymphopoietin production by interleukin-4-primed human mast cells. Eur. Respir. J. 34, 425-435.

Okayama, Y., Saito, H., and Ra, C. (2008). Targeting human mast cells expressing g-protein-coupled receptors in allergic diseases. Allergol. Int. 57, 197-203.

Olivera, A. (2008). Unraveling the complexities of sphingosine-1phosphate function: the mast cell model. Prostaglandins Other Lipid Mediat. 86, 1-11.

Oliver-Vila, I., Saborit-Villarroya, I., Engel, P., and Martin, M. (2008). The leukocyte receptor CD84 inhibits Fc epsilon RI-mediated signaling through homophilic interaction in transfected RBL-2H3 cells. Mol. Immunol. 45, 2138-2149.

Olson, T. S., and Ley, K. (2002). Chemokines and chemokine receptors in leukocyte trafficking. Am. J. Physiol. Regul. Integr. Comp. Physiol. 283, R7-R28.

Omoto, Y., Tokime, K., Yamanaka, K., Habe, K., Morioka, T., Kurokawa, I., Tsutsui, H., Yamanishi, K.,
Nakanishi, K., and Mizutani, $\mathrm{H}$. (2006). Human mast cell chymase cleaves pro-IL-18 and generates a novel and biologically active IL-18 fragment. J. Immunol. 177, 8315-8319.

Ono, E., Taniguchi, M., Higashi, N., Mita, H., Kajiwara, K., Yamaguchi, H., Tatsuno, S., Fukutomi, Y., Tanimoto, H., Sekiya, K., Oshikata C., Tsuburai, T., Tsurikisawa, N., Otomo, M., Maeda, Y., Hasegawa, M., Miyazaki, E., Kumamoto, T., and Akiyama, K. (2010). CD203c expression on human basophils is associated with asthma exacerbation. J. Allergy Clin. Immunol. 125, 483-489 e483.

Orinska, Z., Maurer, M. Mirghomizadeh, F., Bulanova, E., Metz, M., Nashkevich, N., Schiemann, F., Schulmistrat, J., Budagian, V., Giron-Michel, J., Brandt, E., Paus, R., and Bulfone-Paus, S. (2007). IL-15 constrains mast celldependent antibacterial defenses by suppressing chymase activities. Nat. Med. 13, 927-934.

Oshikawa, K., Kuroiwa, K., Tago, K., Iwahana, H., Yanagisawa, K., Ohno, S., Tominaga, S. I., and Sugiyama, Y. (2001). Elevated soluble ST2 protein levels in sera of patients with asthma with an acute exacerbation. Am. J. Respir. Crit. Care Med. 164, 277-281.

Oskeritzian, C. A., Price, M. M., Hait, N. C., Kapitonov, D., Falanga, Y. T., Morales, J. K., Ryan, J. J., Milstien, S., and Spiegel, S. (2010). Essential roles of sphingosine-1phosphate receptor 2 in human mast cell activation, anaphylaxis, and pulmonary edema. J. Exp. Med. 207, 465-474.

Pacher, P., and Mechoulam, R. (2011). Is lipid signaling through cannabinoid 2 receptors part of a protective system? Prog. Lipid Res. 50, 193-211.

Park, L. S., Martin, U., Garka, K., Gliniak, B., di Santo, J. P., Muller, W., Largaespada, D. A., Copeland, N. G., Jenkins, N. A., Farr, A. G., Ziegler, S. F., Morrissey, P. J., Paxton, R., and Sims, J. E. (2000). Cloning of the murine thymic stromal lymphopoietin (TSLP) receptor: formation of a functional heteromeric complex requires interleukin 7 receptor. J. Exp. Med. 192, 659-670.

Paruchuri, S., Tashimo, H., Feng, C. Maekawa, A., Xing, W., Jiang, Y., Kanaoka, Y., Conley, P., and Boyce, J. A. (2009). Leukotriene E4-induced pulmonary inflammation is mediated by the P2Y12 receptor. J. Exp. Med. 206, 2543-2555.

Pegram, H. J., Andrews, D. M., Smyth, M. J., Darcy, P. K., and Kershaw, M.
H. (2011). Activating and inhibitory receptors of natural killer cells. Immunol. Cell Biol. 89, 216-224.

Pertwee, R. G. (2006). The pharmacology of cannabinoid receptors and their ligands: an overview. Int. J. Obes. (Lond.) 30(Suppl. 1), S13-S18.

Pietrzak, A., Wierzbicki, M., Wiktorska, M., and Brzezinska-Blaszczyk, E. (2011). Surface TLR2 and TLR4 expression on mature rat mast cells can be affected by some bacterial components and proinflammatory cytokines. Mediators Inflamm. 2011, 427-473.

Pillot, C., Heron, A., Cochois, V., Tardivel-Lacombe, J., Ligneau, X., Schwartz, J. C., and Arrang, J. M. (2002). A detailed mapping of the histamine $\mathrm{H}(3)$ receptor and its gene transcripts in rat brain. Neuroscience 114, 173-193.

Pini, A., Mannaioni, G., PellegriniGiampietro, D., Passani, M. B., Mastroianni, R., Bani, D., and Masini, E. (2012). The role of cannabinoids in inflammatory modulation of allergic respiratory disorders, inflammatory pain and ischemic stroke. Curr. Drug Targets 13, 984-993.

Plater-Zyberk, C., Joosten, L. A. Helsen, M. M., Sattonnet-Roche, P., Siegfried, C., Alouani, S., van de Loo, F. A., Graber, P., Aloni, S., Cirillo, R., Lubberts, E., Dinarello, C. A., van den Berg, W. B., and Chvatchko, Y. (2001). Therapeutic effect of neutralizing endogenous IL-18 activity in the collagen-induced model of arthritis. J. Clin. Invest. 108, 1825-1832.

Price, M. M., Kapitonov, D., Allegood, J., Milstien, S., Oskeritzian, C. A., and Spiegel, S. (2009). Sphingosine1-phosphate induces development of functionally mature chymaseexpressing human mast cells from hematopoietic progenitors. FASEB J. 23, 3506-3515.

Proft, T., and Baker, E. N. (2009). Pili in Gram-negative and Gram-positive bacteria - structure, assembly and their role in disease. Cell. Mol. Life Sci. 66, 613-635.

Ritter, M., El-Nour, H., Hedblad, M. A., Butterfield, J. H., Beck, O., Stephanson, N., Holst, M., Giscombe, R., Azmitia, E. C., and Nordlind, K. (2012). Serotonin and its 5-HT1 receptor in human mastocytosis. Immunopharmacol. Immunotoxicol. 34, 679-685.

Rocha-de-Souza, C. M., Berent-Maoz, B., Mankuta, D., Moses, A. E., and Levi-Schaffer, F. (2008). Human mast cell activation by Staphylococcus aureus: interleukin- 8 and tumor necrosis factor alpha release and 
the role of Toll-like receptor 2 and CD48 molecules. Infect. Immun. 76, 4489-4497.

Rochman, Y., and Leonard, W. J. (2008). Thymic stromal lymphopoietin: a new cytokine in asthma. Curr. Opin. Pharmacol. 8, 249-254.

Rosethorne, E. M., and Charlton, S. J. (2011). Agonist-biased signaling at the histamine $\mathrm{H} 4$ receptor: JNJ7777120 recruits beta-arrestin without activating G proteins. Mol. Pharmacol. 79, 749-757.

Rozniecki, J. J., Letourneau, R., Sugiultzoglu, M., Spanos, C., Gorbach, J., and Theoharides, T. C. (1999). Differential effect of histamine 3 receptor-active agents on brain, but not peritoneal, mast cell activation. J. Pharmacol. Exp. Ther. 290, 1427-1435.

Sabato, V., Verweij, M. M., Bridts, C. H., Levi-Schaffer, F., Gibbs, B. F., de Clerck, L. S., Schiavino, D., and Ebo, D. G. (2012). CD300a is expressed on human basophils and seems to inhibit IgE/FcepsilonRIdependent anaphylactic degranulation. Cytometry B Clin. Cytom. 82, 132-138.

Sanchez, T., Skoura, A., Wu, M. T., Casserly, B., Harrington, E. O., and Hla, T. (2007). Induction of vascular permeability by the sphingosine-1phosphate receptor-2 (S1P2R) and its downstream effectors ROCK and PTEN. Arterioscler. Thromb. Vasc. Biol. 27, 1312-1318.

Shikotra, A., Choy, D. F., Ohri, C. M., Doran, E., Butler, C., Hargadon, B., Shelley, M., Abbas, A. R., Austin, C. D., Jackman, J., Wu, L. C., Heaney, L. G., Arron, J. R., and Bradding, P. (2012). Increased expression of immunoreactive thymic stromal lymphopoietin in patients with severe asthma. J. Allergy Clin. Immunol. 129, 104-111 e101-109.

Shin, J. S., and Abraham, S. N. (2001). Glycosylphosphatidylinositolanchored receptor-mediated bacterial endocytosis. FEMS Microbiol. Lett. 197, 131-138.

Silver, M. R., Margulis, A., Wood, N., Goldman, S. J., Kasaian, M., and Chaudhary, D. (2010). IL-33 synergizes with IgE-dependent and IgE-independent agents to promote mast cell and basophil activation. Inflamm. Res. 59, 207-218.

Simhadri, V. R., Andersen, J. F., Calvo, E., Choi, S. C., Coligan, J. E., and Borrego, F. (2012). Human CD300a binds to phosphatidylethanolamine and phosphatidylserine, and modulates the phagocytosis of dead cells. Blood 119, 2799-2809.
Slominski, A., Wortsman, J., Pisarchik, A., Zbytek, B., Linton, E. A., Mazurkiewicz, J. E., and Wei, E. T. (2001). Cutaneous expression of corticotropin-releasing hormone $(\mathrm{CRH})$, urocortin, and CRH receptors. FASEB J. 15, 1678-1693.

Smrz, D., Iwaki, S., Mcvicar, D. W., Metcalfe, D. D., and Gilfillan, A. M. (2010). TLR-mediated signaling pathways circumvent the requirement for DAP12 in mast cells for the induction of inflammatory mediator release. Eur. J. Immunol. 40, 3557-3569.

Spiegel, S., and Milstien, S. (2011) The outs and the ins of sphingosine-1-phosphate in immunity. Nat. Rev. Immunol. 11, 403-415.

Steiner, M. A., and Wotjak, C. T. (2008). Role of the endocannabinoid system in regulation of the hypothalamicpituitary-adrenocortical axis. Prog. Brain Res. 170, 397-432.

Sugawara, K., Biro, T., Tsuruta, D., Toth, B. I., Kromminga, A., Zakany, N., Zimmer, A., Funk, W., Gibbs, B. F., Zimmer, A., and Paus, R. (2012). Endocannabinoids limit excessive mast cell maturation and activation in human skin. J. Allergy Clin. Immunol. 129, 726-738.

Supajatura, V., Ushio, H., Nakao, A., Akira, S., Okumura, K., Ra, C., and Ogawa, H. (2002). Differential responses of mast cell Toll-like receptors 2 and 4 in allergy and innate immunity. J. Clin. Invest. 109, 1351-1359.

Tajima, S., Oshikawa, K., Tominaga, S., and Sugiyama, Y. (2003). The increase in serum soluble ST2 protein upon acute exacerbation of idiopathic pulmonary fibrosis. Chest 124, 1206-1214.

Takai, T. (2012). TSLP expression: cellular sources, triggers, and regulatory mechanisms. Allergol. Int. 61, 3-17.

Takeshita, K., Sakai, K., Bacon, K. B., and Gantner, F. (2003). Critical role of histamine $\mathrm{H} 4$ receptor in leukotriene B4 production and mast cell-dependent neutrophil recruitment induced by zymosan in vivo. J. Pharmacol. Exp. Ther. 307, 1072-1078.

Tateno, H., Crocker, P. R., and Paulson, J. C. (2005). Mouse Siglec-F and human Siglec-8 are functionally convergent paralogs that are selectively expressed on eosinophils and recognize $6^{\prime}$-sulfo-sialyl Lewis X as a preferred glycan ligand. Glycobiology 15, 1125-1135.

Taylor, B. C., Zaph, C., Troy, A. E., Du, Y., Guild, K. J., Comeau, M. R., and Artis, D. (2009). TSLP regulates intestinal immunity and inflammation in mouse models of helminth infection and colitis. J. Exp. Med. 206, 655-667.

Theoharides, T. C., Singh, L. K., Boucher, W., Pang, X., Letourneau, R., Webster, E., and Chrousos, G. (1998). Corticotropin-releasing hormone induces skin mast cell degranulation and increased vascular permeability, a possible explanation for its proinflammatory effects. Endocrinology 139, 403-413.

Thomassen, E., Bird, T. A., Renshaw, B. R., Kennedy, M. K., and Sims, J. E. (1998). Binding of interleukin-18 to the interleukin-1 receptor homologous receptor IL-1Rrp1 leads to activation of signaling pathways similar to those used by interleukin1. J. Interferon Cytokine Res. 18 1077-1088.

Tilly, B. C., Tertoolen, L. G., Remorie, R., Ladoux, A., Verlaan, I., de Laat, S. W., and Moolenaar, W. H. (1990). Histamine as a growth factor and chemoattractant for human carcinoma and melanoma cells: action through $\mathrm{Ca} 2(+)$-mobilizing H1 receptors. J. Cell Biol. 110, 1211-1215.

Van Kolen, K., and Slegers, H. (2006). Integration of $\mathrm{P} 2 \mathrm{Y}$ receptoractivated signal transduction pathways in $G$ protein-dependent signalling networks. Purinergic Signal. 2, 451-469.

Vieira, R. P., Muller, T., Grimm, M. Von Gernler, V., Vetter, B., Durk, T., Cicko, S., Ayata, C. K., Sorichter, S. Robaye, B., Zeiser, R., Ferrari, D. Kirschbaum, A., Zissel, G., Virchow, J. C., Boeynaems, J. M., and Idzko, M. (2011). Purinergic receptor type 6 contributes to airway inflammation and remodeling in experimental allergic airway inflammation. Am. J. Respir. Crit. Care Med. 184, 215-223.

Villadsen, L. S., Schuurman, J. Beurskens, F., Dam, T. N., DagnaesHansen, F., Skov, L., Rygaard, J., Voorhorst-Ogink, M. M., Gerritsen, A. F., Van Dijk, M. A., Parren, P. W. Baadsgaard, O., and van de Winkel, J. G. (2003). Resolution of psoriasis upon blockade of IL-15 biological activity in a xenograft mouse model. J. Clin. Invest. 112, 1571-1580.

Waldmann, T. A. (2004). Targeting the interleukin-15/interleukin15 receptor system in inflammatory autoimmune diseases. Arthritis Res. Ther. 6, 174-177.

Waldmann, T. A. (2006). The biology of interleukin-2 and interleukin-15: implications for cancer therapy and vaccine design. Nat. Rev. Immunol. 6, 595-601.
Wang, L., Gantz, I., and Delvalle, J. (1996). Histamine H2 receptor activates adenylate cyclase and PLC via separate GTP-dependent pathways. Am. J. Physiol. 271, G613-G620.

Wang, Y. H., and Liu, Y. J. (2007). OX40OX40L interactions: a promising therapeutic target for allergic diseases? J. Clin. Invest. 117, 3655-3657.

Wang, Z., Lai, Y., Bernard, J. J., Macleod, D. T., Cogen, A. L., Moss, B., and Di Nardo, A. (2012). Skin mast cells protect mice against vaccinia virus by triggering mast cell receptor S1PR2 and releasing antimicrobial peptides. J. Immunol. 188, 345-357.

Wiener, Z., Pocza, P., Racz, M., Nagy, G., Tolgyesi, G., Molnar, V., Jaeger, J., Buzas, E., Gorbe, E., Papp, Z., Rigo, J., and Falus, A. (2008). IL-18 induces a marked gene expression profile change and increased Ccl1 (I309) production in mouse mucosal mast cell homologs. Int. Immunol. 20, 1565-1573.

Willox, I., Mirkina, I., Westwick, J., and Ward, S. G. (2010). Evidence for PI3K-dependent CXCR3 agonistinduced degranulation of human cord blood-derived mast cells. Mol. Immunol. 47, 2367-2377.

Woolley, D. E., and Tetlow, L. C. (2000). Mast cell activation and its relation to proinflammatory cytokine production in the rheumatoid lesion. Arthritis Res. 2, 65-74.

Wu, H. J., and Bondada, S. (2009). CD72, a coreceptor with both positive and negative effects on B lymphocyte development and function. J. Clin. Immunol. 29, 12-21.

Xu, D., Jiang, H. R., Kewin, P., Li, Y., $\mathrm{Mu}$, R., Fraser, A. R., Pitman, N., Kurowska-Stolarska, M., Mckenzie, A. N., Mcinnes, I. B., and Liew, F. Y. (2008). IL-33 exacerbates antigeninduced arthritis by activating mast cells. Proc. Natl. Acad. Sci. U.S.A. 105, 10913-10918.

Ying, S., O'Connor, B., Ratoff, J., Meng, Q., Fang, C., Cousins, D., Zhang, G., Gu, S., Gao, Z., Shamji, B., Edwards, M. J., Lee, T. H., and Corrigan, C. J. (2008). Expression and cellular provenance of thymic stromal lymphopoietin and chemokines in patients with severe asthma and chronic obstructive pulmonary disease. J. Immunol. 181, 2790-2798.

Ying, S., O'Connor, B., Ratoff, J., Meng, Q., Mallett, K., Cousins, D., Robinson, D., Zhang, G., Zhao, J., Lee, T. H., and Corrigan, C. (2005). Thymic stromal lymphopoietin expression is increased in asthmatic airways and correlates with expression of Th2-attracting 
chemokines and disease severity. J. Immunol. 174, 8183-8190.

Yip, K. H., Wong, L. L., and Lau, H. Y. (2009). Adenosine: roles of different receptor subtypes in mediating histamine release from human and rodent mast cells. Inflamm. Res. 58(Suppl. 1), 17-19.

Yokoi, H., Choi, O. H., Hubbard, W., Lee, H. S., Canning, B. J., Lee, H. H., Ryu, S. D., Von Gunten, S., Bickel, C. A., Hudson, S. A., Macglashan, D. W. Jr., and Bochner, B. S. (2008). Inhibition of FcepsilonRI-dependent mediator release and calcium flux from human mast cells by sialic acid-binding immunoglobulin-like lectin 8 engagement. J. Allergy Clin. Immunol. 121, 499-505 e491.

Yoo, J., Omori, M., Gyarmati, D., Zhou, B., Aye, T., Brewer, A., Comeau, M. R., Campbell, D. J., and Ziegler, S. F. (2005). Spontaneous atopic dermatitis in mice expressing an inducible thymic stromal lymphopoietin transgene specifically in the skin. J. Exp. Med. 202, 541-549.

Young, M. R., and Matthews, J. P. (1995). Serotonin regulation of T-cell subpopulations and of macrophage accessory function. Immunology 84, 148-152.

Yu, S., Stahl, E., Li, Q., and Ouyang, A. (2008). Antigen inhalation induces mast cells and eosinophils infiltration in the guinea pig esophageal epithelium involving histaminemediated pathway. Life Sci. 82, 324-330.

Zhang, F., Huang, G., Hu, B., Song, Y., and Shi, Y. (2011). A soluble thymic stromal lymphopoietin (TSLP) antagonist, TSLPRimmunoglobulin, reduces the severity of allergic disease by regulating pulmonary dendritic cells. Clin. Exp. Immunol. 164, 256-264.

Zhu, Y., Michalovich, D., Wu, H., Tan, K. B., Dytko, G. M., Mannan, I. J.,
Boyce, R., Alston, J., Tierney, L. A., Li, X., Herrity, N. C., Vawter, L., Sarau, H. M., Ames, R. S., Davenport, C. M., Hieble, J. P., Wilson, S., Bergsma, D. J., and Fitzgerald, L. R. (2001). Cloning, expression, and pharmacological characterization of a novel human histamine receptor. Mol. Pharmacol. 59, 434-441.

Ziegler, S. F., and Artis, D. (2010) Sensing the outside world: TSLP regulates barrier immunity. Nat. Immunol. 11, 289-293.

Zimmermann, N., King, N. E., Laporte, J., Yang, M., Mishra, A., Pope, S. M., Muntel, E. E., Witte, D. P., Pegg, A. A., Foster, P. S., Hamid, Q., and Rothenberg, M. E. (2003). Dissection of experimental asthma with DNA microarray analysis identifies arginase in asthma pathogenesis. $J$. Clin. Invest. 111, 1863-1874.

Conflict of Interest Statement: The authors declare that the research was conducted in the absence of any commercial or financial relationships that could be construed as a potential conflict of interest.

Received: 23 April 2012; accepted: 16 July 2012; published online: 02 August 2012. Citation: Migalovich-Sheikhet H, Friedman S, Mankuta D and Levi-Schaffer $F$ (2012) Novel identified receptors on mast cells. Front. Immun. 3:238. doi: 10.3389/fimmu.2012.00238

This article was submitted to Frontiers in Molecular Innate Immunity, a specialty of Frontiers in Immunology.

Copyright (c) 2012 Migalovich-Sheikhet, Friedman, Mankuta and Levi-Schaffer. This is an open-access article distributed under the terms of the Creative Commons Attribution License, which permits use, distribution and reproduction in other forums, provided the original authors and source are credited and subject to any copyright notices concerning any third-party graphics etc. 